\title{
Introgression between ecologically distinct species following increased salinity in the Colorado Delta- Worldwide implications for impacted estuary diversity
}

\author{
Clive L.F. Lau ${ }^{1}{ }^{\text {, David K. Jacobs }}{ }^{\text {Corresp. } 1}$ \\ ${ }^{1}$ Department of Ecology and Evolutionary Biology, University of California, Los Angeles, Los Angeles, California, United States \\ Corresponding Author: David K. Jacobs \\ Email address: djacobs@ucla.edu
}

We investigate hybridization and introgression between ecologically distinct sister species of silverside fish in the Gulf of California through combined analysis of morphological, sequence, and genotypic data. Water diversions in the past century turned the Colorado River Delta from a normal estuary to a hypersaline inverse estuary, raising concerns for the local fauna, much of which is endangered. Salinity differences are known to generate ecological species pairs and we anticipated that loss of the fresher-water historic salinity regime could alter the adaptive factors maintaining distinction between the broadly distributed Gulf-endemic Colpichthys regis and the narrowly restricted Delta-endemic Colpichthys hubbsi, the species that experienced dramatic environmental change. In this altered environmental context, these long-isolated species (as revealed by Cytochrome $b$ sequences) show genotypic (RAG1, microsatellites) evidence of active hybridization where the species ranges abut, as well as directional introgression from $C$. regis into the range center of $C$. hubbsi. Bayesian group assignment (STRUCTURE) on six microsatellite loci and multivariate analyses (DAPC) on both microsatellites and phenotypic data further support substantial recent admixture between the sister species. Although we find no evidence for recent population decline in $C$. hubbsi based on mitochondrial sequence, introgression may be placing an ancient ecological species at risk of extinction. Such introgressive extinction risk should also pertain to other ecological species historically sustained by the now changing Delta environment. More broadly, salinity gradient associated ecological speciation is evident in silverside species pairs in many estuarine systems around the world. Ecological species pairs among other taxa in such systems are likely poorly understood or cryptic. As water extraction accelerates in river systems worldwide, salinity gradients will necessarily be altered, impacting many more estuary and delta systems. Such alteration of habitats will place biodiversity at risk not only from direct effects of habitat destruction, but also from the potential for the breakdown of ecological species. Thus, evolutionary response to the anthropogenic alteration of salinity gradients in 
estuaries merits investigation as the number of impacted systems increases around the globe, permitting parallel study of multiple systems, while also permitting a conservation management response to help preserve this little championed component of biodiversity. 
Introgression between ecologically distinct species following increased salinity in the Colorado Delta- Worldwide implications for impacted estuary diversity

Clive L. F. Lau, ${ }^{1}$ and David K. Jacobs ${ }^{2}$

1,2 Department of Ecology and Evolutionary Biology, University of California, Los Angeles, Los Angeles, California, USA

Corresponding Author:

David K. Jacobs ${ }^{2}$

Email address:

djacobs@ucla.edu 


\section{Abstract}

2 We investigate hybridization and introgression between ecologically distinct sister species of

3 silverside fish in the Gulf of California through combined analysis of morphological, sequence,

4 and genotypic data. Water diversions in the past century turned the Colorado River Delta from a

5 normal estuary to a hypersaline inverse estuary, raising concerns for the local fauna, much of

6 which is endangered. Salinity differences are known to generate ecological species pairs and we

7 anticipated that loss of the fresher-water historic salinity regime could alter the adaptive factors

8 maintaining distinction between the broadly distributed Gulf-endemic Colpichthys regis and the

9 narrowly restricted Delta-endemic Colpichthys hubbsi, the species that experienced dramatic

10 environmental change. In this altered environmental context, these long-isolated species (as

11 revealed by Cytochrome $b$ sequences) show genotypic (RAG1, microsatellites) evidence of

12 active hybridization where the species ranges abut, as well as directional introgression from $C$.

13 regis into the range center of $C$. hubbsi. Bayesian group assignment (STRUCTURE) on six

14 microsatellite loci and multivariate analyses (DAPC) on both microsatellites and phenotypic data

15 further support substantial recent admixture between the sister species. Although we find no

16 evidence for recent population decline in C. hubbsi based on mitochondrial sequence,

17 introgression may be placing an ancient ecological species at risk of extinction. Such

18 introgressive extinction risk should also pertain to other ecological species historically sustained

19 by the now changing Delta environment. More broadly, salinity gradient associated ecological

20 speciation is evident in silverside species pairs in many estuarine systems around the world.

21 Ecological species pairs among other taxa in such systems are likely poorly understood or

22 cryptic. As water extraction accelerates in river systems worldwide, salinity gradients will

23 necessarily be altered, impacting many more estuary and delta systems. Such alteration of 
24 habitats will place biodiversity at risk not only from direct effects of habitat destruction, but also 25 from the potential for the breakdown of ecological species. Thus, evolutionary response to the 26 anthropogenic alteration of salinity gradients in estuaries merits investigation as the number of 27 impacted systems increases around the globe, permitting parallel study of multiple systems, 28 while also permitting a conservation management response to help preserve this little 29 championed component of biodiversity. 


\section{INTRODUCTION}

Damming and water extraction in river systems are accelerating around the globe

32 (Nilsson et al., 2005; Liermann et al., 2012), impacting estuarine and deltaic settings downstream

33 (Bonetto et al., 1989; Lu and Siew, 2006; Yang et al., 2005). Physical changes include loss of

34 freshwater, elimination of peak flood flows, loss of sediment supply, and alteration of the nature

35 and position of salinity gradients (Nilsson and Berggren, 2000, Carriquiry and Sánchez, 1999).

36 Such changes necessarily influence the adaptive context under which local species evolve,

37 potentially reducing the selective pressures maintaining species differences and placing ecological species at risk of elimination through introgression. In order to better understand the risks such changes pose, we examine recent introgression in a Pliocene-age species pair of silverside fishes of the genus Colpichthys in the northern Gulf of California (Gulf hereafter) where the Colorado River enters the Ocean. Following 20th century dam constructions, virtually no river flow reaches the Colorado River Delta (Glenn et al., 1996). As a consequence of this dramatically modified state, this system may serve as a harbinger of evolutionary impacts in the estuaries of the world's major river systems.

Colpichthys, a little studied genus of the silverside family Atherinopsidae, inhabits nearshore settings of the northern part of the Gulf and consists of two endemic species, Colpichthys regis (Jenkins and Evermann, 1889) and Colpichthys hubbsi (Crabtree, 1989). These are listed on the IUCN Red List as Near Threatened and Endangered, respectively (Findley et al., 2010a; Findley et al., 2010b). The Colorado River enters the Gulf at its northernmost extremity where it forms an extensive delta and estuary system. The Colorado Delta (Delta hereafter) habitat of $C$. hubbsi was historically distinct from the other marine estuaries of the semiarid Gulf where we recovered C. regis samples (Crabtree, 1989; Hastings and Findley, 2007). Tidal channels in the 
53 Delta experience a much greater tidal amplitude of up to 10 meters, and silt as opposed to clay

54 content is much higher in the Delta relative to other estuaries. In the 19th century, the Delta

55 received continuous freshwater flow and extensive flood water during the spring and summer

56 melting of mountain snows in the headwaters. These flows were eliminated through 20th century

57 damming leading to a shift from a typical brackish to a hypersaline inverse estuary (Lavín and

58 Sánchez, 1999). The difference in salinity, sediment supply and food chain necessarily impose

59 significantly different adaptive regimes on taxa in the Delta relative to other Gulf estuaries (Swift

60 et al., 2011); as a result of the shifting environment, these differences may disappear.

61 Through the study of introgressive process in Colpichthys we hope to inform issues of

62 evolution and endangerment of the northern Gulf fauna associated with the potential for

63 introgression in ecological species in the face of habitat change. Direct and climate driven

64 anthropogenic impacts increasingly threaten estuarine faunas globally across a broader suite of

65 river systems. In the remainder of this introduction we consider: similar contexts that have

66 produced ecological species, the potential extirpation of species via introgression, the relevant

67 detail regarding the study taxon Colpichthys as well as the suite of data and methods employed in

68 phylogeny reconstruction, and assessment of historic demography and introgression.

Marine taxa that invade fresh water experience strong selection (Lee, 2015). In these

cases, advantages in food availability or predator avoidance can overcome the selective costs and

71 rapid evolution of tolerance to fresh water often ensues. Ecological divergence between fresh and

72 marine water commonly occurs in the lower reaches of rivers, and is especially well established

73 in silversides. Ecological diversification and speciation by salinity differences occur in

74 geographically isolated and taxonomically separate silverside genera from Brazil, Australia, the

75 Mediterranean, and the Eastern US (Bamber and Henderson, 1988; Beheregaray and Sunnucks, 
76 2001; Fluker et al., 2011; Johnson et al., 1994; Klossa-Kilia et al., 2007; Francisco et al., 2006;

77 Olsen et al., 2016; Trabelsi et al., 2002). The strong selection pressures between fresh and salt water, the frequent ecological diversification in silversides, and the historic difference in habitats between the Delta and the Gulf as noted above all support an ecological species interpretation of the $C$. regis/C. hubbsi split. As the loss of fresh water input to the Delta disrupts the local salinity

81 gradient, breakdown of the ecological factors supporting distinction of these species seems 82 likely.

Introgressive hybridization involves the transfer of alleles from one species to the gene pool of another species through repeated backcrossing of hybrids (Heiser, 1973; Harrison and Larson, 2014). This process can result from the dissolution of selective regimes that maintain ecological species and has a number of evolutionary consequences. Introgression could allow for the spread of adaptive or deleterious alleles from one species to the other across a hybrid zone. Alternatively, it may promote the homogenization of the two species, and in extreme cases, could lead to the extinction of one or both parental types through effects such as demographic or genetic swamping (Todesco et al., 2016). The hydrologic changes in the Delta make C. hubbsi a

91 likely candidate for introgressive hybridization with C. regis. C. regis has a range rendered discontinuous by the Colorado River Delta at the northern end of the Gulf where C. hubbsi is locally endemic. C. regis and C. hubbsi co-occur only at the southwestern border of the Delta where it meets the Baja coast (Fig. 1A). In this study, we test whether hybridization occurs in this region of overlap and whether introgression is occurring between the species. recovered from $C$. regis and $C$. hubbsi populations to characterize the variation across both species to help establish baseline for discovering potential hybrids. We also investigate 
99 molecular evidence from mitochondrial and nuclear sequences as well as microsatellite

100 genotypes to detect genetic introgression across the species barrier. In addition to investigating

101 the hybridization, with the available genetic data we performed a number of population genetics

102 analyses to infer genetic diversity and demographic histories of the two species.

103

104 Materials ANd Methods

105 Sample Collection

106 Specimens of the genus Colpichthys were collected by seine from estuarine habitats along

107 the coast of the Northern Gulf of California and within the Colorado River Delta in the years

108 2005, 2006, 2007, and 2011 (Table 1). Collections were carried under Mexican Federal

109 Collecting Permit (Permiso de Pesca de Fomento) DGOPA 14253. 101005.6950, and its

110 extension DGOPA 06435.210606.2640, issued to Findley and Jacobs by the Comisión Nacional

111 de Acuacultura y Pesca of the Secretaría de Agricultura, Ganadería, Desarrollo Rural, Pesca y

112 Alimentación (SAGARPA). Collected specimens were preserved in 95\% ethanol in the field and

113 stored at $-20^{\circ} \mathrm{C}$ upon returning to the laboratory for use in both molecular and morphological

114 analyses. For this study, we divided the coastline of the Northern Gulf of California into 4

115 regions: (1) the Delta, native to populations of C. hubbsi; (2) the Baja Coast and (3) the Sonora

116 Coast, native to populations of C. regis; and (4) the Delta Edge, the putative hybrid zone. A full

117 list of collection sites along with the abbreviated designation for each site are shown in Table 1.

118 In addition to the field-collected specimens, formalin-fixed specimens from the Natural History

119 Museum of Los Angeles County (LACM) and Scripps Institution of Oceanography were

120 examined for their morphology to confirm species identification. A list of these "historical"

121 specimens is included in the supplementary materials (Table 2). 
123 Phenotypic Analyses

124 The dorsal-lateral scale counts, vertebral counts, hemal spine morphology, and the

125 position of the first dorsal fin were used as species-distinguishing features for this study; these

126 features were chosen based on the species description of Colpichthys hubbsi (Crabtree, 1989).

127 The first dorsal fin position is assessed based on the linear length from the snout to the first

128 dorsal fin origin, normalized by the standard length. Length measurements were taken with dial

129 calipers. Morphometric and meristic counts were performed according to Hubbs et al. (2004).

130 Radiographs of specimens were taken for examination of their vertebral counts and hemal spine

131 morphology. Six specimens from location NWC and 3 specimens from location YAV were too

132 small to accurately assess their hemal spine morphology; they were thus excluded from the

133 hemal spine data set.

Molecular Procedures

136 Genomic DNA was isolated from caudal peduncle muscle tissues using the DNeasy

137 Blood and Tissue Kit (Qiagen, Inc., Valencia, CA). The mitochondrial cytochrome $b$ gene was

138 amplified by PCR using primers AJG15 and H5 (Akihito et al., 2000) under the following

139 cycling conditions: $95^{\circ} \mathrm{C}$ for $2 \mathrm{~min} ; 40$ cycles of $95^{\circ} \mathrm{C}$ for $30 \mathrm{sec}, 51^{\circ} \mathrm{C}$ for $30 \mathrm{sec}$, followed by

$14072^{\circ} \mathrm{C}$ for $90 \mathrm{sec}$; then finally $72^{\circ} \mathrm{C}$ for $10 \mathrm{~min}$. PCR products were size-checked on $1.5 \%$ agarose

141 gel and cleaned with ExoSap before Sanger sequencing with BigDye Terminator v3.1. Samples

142 were then submitted to DNA Analysis Facility on Science Hill at Yale University for capillary

143 electrophoresis. 

RAG1-4090R (López et al., 2004) under the following cycling conditions: $95^{\circ} \mathrm{C}$ for $2 \mathrm{~min} ; 40$ cycles of $95^{\circ} \mathrm{C}$ for $1 \mathrm{~min}, 51^{\circ} \mathrm{C}$ for $1 \mathrm{~min}$ with an incremental increase of $0.5^{\circ} \mathrm{C}$ per cycle until $55^{\circ} \mathrm{C}$, followed by $72^{\circ} \mathrm{C}$ for $90 \mathrm{sec}$; then finally $72^{\circ} \mathrm{C}$ for $10 \mathrm{~min}$. Post-PCR processing and sequencing of the RAG1 gene were performed as described above. From the sequences, we were able to identify four polymorphic sites; several individuals display ambiguity in base calling at such sites, and these were tagged as putative heterozygotes. A total of four RAG1 variants were inferred from the sequence data. Homozygous individuals were used to confirm the existence of three RAG1 variants; the remaining RAG1 variant was inferred from a heterozygous individual.

153 To confirm the gametic phase of these RAG1 sequences, we employed allele-specific

154 polymerase chain reaction (ASPCR) as detailed in Wu et al. (1989). Three allele-specific primers 155 (T717F: 5'-CTACAAAATCTTCCAGGAT-3', T770R: 5'-

\section{TTTATCTAAGGCTGCCCTCCAGA-3', and A909F: 5'-AACTGGTGCCCTCAGAAGAA-3')} were designed to uniquely amplify one of the two diploid copies of RAG1 in the putative heterozygotes. The $3^{\prime}$ terminating nucleotide of these primers are designed to specifically anneal

159 at the predetermined polymorphic site, thus enabling unique amplification of alleles and 160 determination of the RAG1 genotypes of the heterozygotes.

161 Six microsatellite loci (Odont08, Odont09, Odont11, B18, B19, B39) were amplified for 162 genotyping. Primer sequences for loci Odont08, Odont09, and Odont11 were obtained from

163 Beheregaray and Sunnucks (2000). Primer sequences for loci B18, B19, B39 were obtained from

164 Byrne and Avise (2009). Loci which can be easily differentiated by lengths were multiplexed 165 two at a time using QIAGEN Multiplex PCR kits with 6-FAM labeled M13 primer (Boutin166 Ganache et al. 2001). Only the forward primers of each locus are 5' tagged with the M13 
167 sequence, and reactions were performed under the following cycling conditions: $95^{\circ} \mathrm{C}$ for 15

$168 \mathrm{~min} ; 25$ cycles of $94^{\circ} \mathrm{C}$ for $30 \mathrm{sec}, 55^{\circ} \mathrm{C}$ for $90 \mathrm{sec}, 72^{\circ} \mathrm{C}$ for $1 \mathrm{~min}$; then another 25 cycles of

$16994^{\circ} \mathrm{C}$ for $30 \mathrm{sec}, 50^{\circ} \mathrm{C}$ for $90 \mathrm{sec}, 72^{\circ} \mathrm{C}$ for $1 \mathrm{~min}$; and finally $60^{\circ} \mathrm{C}$ for $30 \mathrm{~min}$. Diluted PCR

170 products were submitted to the UCLA GenoSeq core facility for genotyping on an ABI3730

171 (Applied Biosystems).

172

173 Molecular Analyses

174 All sequences were aligned, trimmed, and analyzed using Geneious Pro ver. 5.5.6

175 (Drummond et al., 2011). A Maximum Likelihood tree of Cyt $b$ sequence was made with

176 MEGA7 (Kumar et al., 2016) and rooted using Atherinops affinis as the outgroup. A time-

177 calibrated tree was inferred using the Reltime method (Tamura et al. 2012) and the Tamura-Nei

178 model (Tamura and Nei, 1993). The timetree was computed using one calibration constraint at

179 the node of the split between C. regis and C. hubbsi; the calibration point of 4.83Ma was

180 obtained from the age of the ash bed within the Bouse Formation, the rock unit from which two

181 fossilized C. regis were documented (Todd, 1976; Spencer et al., 2013).

182 Microsatellite data were obtained from 101 out of 103 specimens and imported into

183 Geneious for allele scoring and analyzed using STRUCTURE ver. 2.3.4 (Pritchard et al. 2000).

184 STRUCTURE is a program that uses a Bayesian clustering approach to infer population structure

185 from genotypic data. Under an admixture model of K populations or genetic groupings,

186 STRUCTURE computes the q-value, a quantity between 0 and 1 , that reflects the proportions of

187 an individual's genome originating from a certain population. Hybridization can then be inferred

188 based on the computed q-value; for example, first-generation (F1) hybrids of two populations

$189(\mathrm{~K}=2)$ are expected to have a q-value close to 0.5 (Vähä and Primmer, 2006). We ran 
190 STRUCTURE analyses using an admixture model with 1,000,000 MCMC generations after a

191 burn-in period of 100,000. Sampling locations were incorporated as prior parameters in the

192 LOCPRIOR model to improve clustering for our data set; the LOCPRIOR model is preferred

193 when there are weak signals of structure due to low number of markers analyzed (Hubisz et al.,

194 2009). Both correlated and independent allele frequency models were used with number of

195 groups set from $K=1$ to $K=4$; for each $K$ value, analysis was repeated ten times. Of the two allele

196 frequency models, the correlated model provides greater power in differentiating closely related

197 populations (Falush et al., 2003). The optimal K value was informed by $\Delta \mathrm{K}$ (Evanno et al., 2005)

198 as computed using Structure Harvester (Earl et al., 2012). Output of the STRUCTURE analyses

199 were summarized in CLUMPP ver. 1.1.2 (Jakobsson and Rosenberg, 2007) and visualized in

200 DISTRUCT ver. 1.1 (Rosenberg, 2004).

201

202 Multivariate Analysis

203 We further analyzed our phenotypic and microsatellite data by discriminant analysis of

204 principal components (DAPC) using the R-package adegenet (Jombart et al., 2011). This

205 analysis is used to help describe the phenotypic and genetic clustering of our specimens. Cluster

206 priors for DAPC were identified by $k$-means clustering; based on BIC scores we selected the 2-

207 cluster model to use for the DAPC. To perform DAPC, the program transforms the data into 208 principal components, which is then analyzed through discriminant analysis. Repeated cross-

209 validation was used to evaluate the optimal number of principal components to retain for the

210 discriminant analyses to avoid overfitting of data. For the phenotypic analysis, we used

211 measurements of the 4 species-distinguishing features as our data and retained one PC (91.28\%

212 of the cumulative variance) for generating the morphology discriminant function. For the 
213 microsatellite analysis, we used the allele frequencies of the 6 loci as our data and retained 20

214 PCs (66.35\% of the cumulative variance) for generating the microsatellite discriminant function.

215

216 Demographic Histories

217 To explore the demographic histories of Colpichthys, Cyt $b$ data sets were separated by

218 species according to the Cyt $b$ gene tree (Fig. 1B). 44 sequences from C. hubbsi and 52

219 sequences from C. regis were analyzed for their haplotype diversity. Median-joining haplotype

220 networks were drawn in POPART ver. 1.7 (Leigh and Bryant, 2015). Cyt $b$ haplotypes were

221 examined by various neutrality tests - Tajima's $D$ (Tajima, 1989), $\mathrm{Fu}$ and $\mathrm{Li}$ 's $D^{*}$ and $F^{*}(\mathrm{Fu}$

222 and Li, 1993), Fu's $F s$ (Fu, 1997), and $R_{2}$ (Ramos-onsins and Rozas, 2006) - in DnaSP v.

223 5.10.01 (Librado and Rozas, 2009). P-values for these test statistics were obtained by coalescent

224 simulations of 1000 replicates, conditional on the number of segregating sites. Pairwise

225 differences were analyzed by mismatch distributions in Arlequin ver. 3.1 (Excoffier and

226 Schneider, 2005); coalescent simulations were run with 10,000 bootstrap replicates. Past

227 demographic expansions can be inferred from haplotypes based on the mismatch distribution of

228 the pairwise differences; an uneven, multi-modal distribution is expected for populations under

229 demographic equilibrium, whereas a "smooth" uni-modal distribution is expected for populations

230 that had undergone demographic expansion (Rogers and Harpending, 1992). The observed

231 mismatch distributions of the two species were compared to the expected mismatch distribution

232 under a sudden expansion model using the sum of square deviation (SSD) and the raggedness

233 index.

234

235 RESUlts 
236

237

238

239

240

241

242

243

244

245

246

247

248

249

250

251

252

253

254

255

256

257

Pure-bred Specimens of C. regis and C. hubbsi are morphologically distinct

Consistent with the findings of Crabtree (1989), our morphological analysis based on both modern and historical specimens, summarized in Fig. 2, shows that C. regis (green and gold) differs from C. hubbsi (pink) in having higher dorsal-lateral scale counts, higher vertebral counts, and shorter snout to first dorsal fin origin distance. In addition, the symphases of the hemal spines of the anterior-most caudal vertebrae of $C$. regis are modified into an expanded process (Fig. S1), forming a funnel-like structure antero-posteriorly. The number of modified hemal spines within C. regis outside of the Delta Edge varies between 5 to 11; the hemal spines of C. hubbsi in the Delta appears to show no signs of such modification (Fig. 2D). Outside the putative hybrid zone at the Delta Edge, individuals are relatively easily classified to species based on morphological differences. However, more continuous variation is evident within the Delta Edge region.

Introgression of Cytochrome b and RAG1 Haplotypes

Maximum-Likelihood phylogeny reconstruction of Cyt b sequence reveals $\sim 6 \%$

divergent clades corresponding to the two species of Colpichthys (Fig. 1B). C. hubbsi haplotypes were recovered from the Delta region, while Baja and Sonoran Coast samples contained only $C$. regis haplotypes. Both species were expected to cohabit the localities at the southwestern border of the Delta (PRI, SGU, and TRC), but none of these locations contain a mixture of both haplotypes. PRI and SGU fish are all C. regis haplotypes, while the more Delta internal TRC sample is exclusively C. hubbsi haplotypes, albeit with limited sample sizes. Within the Delta, five specimens collected from predominantly C. hubbsi populations-ELZ, CHY, and SFG- 
258 were found to possess the C. regis mitochondrial haplotype; these specimens are

259 morphologically indistinguishable from other C. hubbsi specimens.

260 We identified four RAG1 variants (labeled as $H_{1}, H_{2}, H_{3}$, and $R$; Table 3) based on four

261 polymorphic sites in the RAG1 sequence data (975bp). We find that $H_{1}, H_{2}$, and $H_{3}$ are common

262 in populations of $C$. hubbsi in the Delta, while $R$ is fixed in all populations of $C$. regis in the Baja

263 Coast and Sonora Coast regions. Thus, the two species are well differentiated by their RAG1

264 genotypes, with the diagnostic SNPs at positions 717 and 909. Six specimens, heterozygous at

265 both of these positions, are flagged as putative hybrids. Four of the six hybrids occur at the Delta

266 Edge, while the remaining two are found within the Delta proper (Table 4). No RAG1

267 heterozygotes are detected in any of the Baja and Sonoran collection sites.

268 As noted above, morphology of the anterior-most caudal hemal spines provides a

269 phenotypic difference between the two species of Colpichthys. The non-modified hemal spine

270 phenotype (Fig. S1A) is observed in all specimens possessing any of the three C. hubbsi RAG1

271 alleles $\left(H_{1}, H_{2}\right.$, or $\left.H_{3}\right)$.

272

273 Bayesian Analyses of Microsatellites Show Evidence of Admixture

274 Based on the evaluation of $\Delta K$, the STRUCTURE analyses on the six microsatellite loci

275 recovered two genetically distinct clusters corresponding to the two species of Colpichthys (Fig.

2763 ; for $\mathrm{K}=3$ and $\mathrm{K}=4$, see Fig. S2). Under the admixture model, the q-value represents admixture

277 proportion of each individual. We used a q-value threshold to distinguish putative purebred and

278 hybrid individuals; for optimal efficiency, this threshold is set to 0.1 (Vähä and Primmer, 2006).

279 Populations in the Delta proper-ELZ, SFG, and CHY—were identified as purebred C. hubbsi.

280 Several populations away from the Delta such as ANI, NWC, and YAV were identified as 
281 purebred C. regis. All individuals within or near the western Delta Edge-PRI, SGU, and

282 TRC — show substantial degrees of genetic admixture, having q-values between 0.1 and 0.9 .

283 Moreover, among these populations there appears to be a gradient in q-values as a function of

284 geographic distance from the mouth of the Colorado River. TRC has an average q-value of 0.17

285 while PRI, which is farther from the river mouth, has an average q-value of 0.72 (Fig. 3A). A

286 relatively weak signal for admixture in the ADR population beyond the eastern edge of the delta

287 was detected exclusively in the correlated allele frequency model; this signal is absent in the

288 analysis with the independent allele frequency model (Fig. 3B).

289

290

Consilience of Phenotypic and Nuclear Data

291 Results from separate DAPC analyses were pooled to compare phenotypic and

292 microsatellite variation. Two clusters are supported, consequently only one discriminant

293 function was generated for each of the DAPC analyses. These results show two well separated

294 species with congruent cluster assignment from both data sets (Fig. 3C). Delta Edge specimens

295 preferentially situate between the species clusters. Of the six RAG1 heterozygotes (triangles on

296 Fig. 3C): two recovered in the Delta Edge area fall near the midpoint in morphology between the

297 two species; two recovered in the Delta proper are near the centroid of C. hubbsi and the last two

298 from the Delta Edge are phenotypically more similar to C. hubbsi than C. regis.

299

300 Genetic Diversity and Demographic History

301 The Cyt $b$ median-joining haplotype networks of the two species are displayed in Fig. 4A

302 and Fig. 4B. Twenty-Eight C. hubbsi haplotypes are recovered from the four Delta populations;

303 in contrast, only ten haplotypes are found in C. regis over a larger, more disjunct geographic 
304 range. C. regis haplotype diversity differs substantially between the Baja and the Sonoran

305 Coasts; with the exception of one individual from PRI, all non-major haplotypes are found

306 exclusively in Sonora Coast populations. The major C. regis haplotype is present in all locations

307 outside the Delta except the two southernmost Sonora Coast sites, SLD and YAV. All five

308 individuals within the Delta proper with the $C$. regis Cyt b sequence possess the major

309 haplotype. Neutrality tests were conducted with the exclusion of the mitochondrial-introgressed

310 individuals; all neutrality tests report significant departure from neutrality. Significantly negative

311 values for Tajima's $D$ and Fu's Fs in both species are consistent with either population growth or

312 selective sweep (Table 5). The sum of square deviations and raggedness indices for the mismatch

313 distributions are close to zero and not significant (Table 6), thus we are unable to reject the

314 sudden expansion model for both species. Fig. 4 (C-D) shows the nucleotide mismatch

315 distributions for both species; C. hubbsi has a bimodal distribution, while C. regis has a

316 unimodal distribution that matches closely with the expected curve under sudden expansion.

318 Discussion

319 The Hybrid Zone

320 Crabtree (1989) recognized that the two Colpichthys species co-occur in the region just

321 north of San Felipe, designated the Delta Edge in this study. While external morphology of

322 specimens collected in 1968 confirms the co-occurrence of the two species at this region (Table

$323 \mathrm{~S} 1$ ), there is no indication from these samples of historical hybridization. Our study presents the

324 first evidence for the modern hybridization of the sister species. STRUCTURE and DAPC

325 analyses strongly support our hypothesis that the Delta Edge region currently represents a hybrid

326 zone. STRUCTURE results limited to the correlated allele frequency model raise the possibility 
327 that hybridization may also be occurring on the eastern border of the Delta at Bahía Adair

328 (ADR). The fact that weak admixture signals at ADR are not detected using our other approaches

329 suggests that hybridization at this region, if present, is likely infrequent.

\section{Directional Introgression}

In addition to hybridization at the Delta Edge, we detected C. regis mitochondrial and

333 RAG1 haplotypes near the mouth and upstream along the Colorado Estuary within the Delta.

334 This could be explained by either the dispersal of first generation hybrids from the hybrid zone to

335 the Delta or by multigenerational backcrossing of hybrids with parental C. hubbsi in this case far

336 from the Delta Edge (i.e. introgressive hybridization). Our data lend support to the introgressive

337 hybridization interpretation. Unlike the RAG1 hybrids at the Delta Edge, specimens that possess

338 C. regis mitochondrial and/or RAG1 haplotypes within the Delta do not exhibit intermediate

339 morphology. Morphological and microsatellite data for these specimens are typical for $C$.

340 hubbsi. Thus, they likely represent the product of multiple backcrosses. Thus $C$. regis haplotypes

341 have been introduced into the center of the $C$. hubbsi range via introgressive hybridization.

342 Conversely, we failed to detect any C. hubbsi haplotypes outside of the Delta and Delta Edge

343 regions. Thus, introgression does not appear to be reciprocal, although more sampling south of

344 the Delta Edge would allow a stronger conclusion that $C$. hubbsi haplotypes are absent in

345 predominantly C. regis populations.

Parental Sex Asymmetry in Introgression

348 Phenotypic and microsatellite data (Fig. 3C, Fig. S3) reveal a narrow geographic cline

349 across the $10 \mathrm{~km}$ wide hybrid zone which spans 3 estuaries at the southwestern Delta border- 
350 Estero Primero (PRI), Estero Segundo (SGU), and Estero Tercero (TRC). Yet despite

351 morphological and nuclear evidence of hybridization all thirteen specimens from PRI and SGU

352 possess the $C$. regis mitochondrial haplotype. Given matrilineal mitochondrial inheritance, this

353 pattern may indicate hybridization between female parental C. regis and male parental C. hubbsi.

354 Little is known about the life history and spawning behavior of Colpichthys. However, Crabtree

355 (1989) noted that the ovipositor of C. hubbsi is twice the size of that in C. regis, suggesting that

356 differences in reproductive organs could contribute to the directionality of introgression.

357 Behavioral or ecological differences may also play a role, but these hypotheses have yet to be

358 assessed.

359

360 Timing of Divergence

361 Due to the lack of available genetic data from historical samples, the onset of

362 hybridization cannot be easily constrained. However, the $\sim 6 \%$ mitochondrial sequence

363 divergence between $C$. regis and C. hubbsi suggests that the two species have long been

364 separated with hybridization a relatively recent phenomenon. This mitochondrial divergence is

365 comparable to that of another fish sister species pair, Gillichthys mirabilis and Gillichthys

366 detrusus (Swift et al., 2011), which share distributional patterns with C. regis and C. hubbsi.

367 Like C. hubbsi, G. detrusus is narrowly restricted to the silty tidal channels of the Colorado

368 River Delta; its congener, G. mirabilis, can be found in the estuaries and lagoons on both coasts

369 of the Gulf. Swift at al. (2011) estimated a $\sim 5$ Ma divergence time between G. detrusus and $G$.

370 mirabilis. Given that both C. hubbsi and G. detrusus are Delta endemics, their divergences from

371 their sister species may have been linked to the formation of the Delta estuaries, which occurred

372 after the opening of the Gulf of California. Fossils of $C$. regis have been discovered in the Bouse 
373 Formation at the location of Cibola Lake, Arizona (Todd, 1976). The Bouse Formation records

374 the changing depositional environments associated with Late Miocene/Early Pliocene

375 progression of the Colorado River to the Gulf (Poulson and John, 2003; McDougall and Miranda

376 Martinez, 2014; Spencer and Patchett, 1997; Roskowski et al. 2010). Stratigraphic and tectonic

377 reconstructions suggest that the Colorado River reached the Gulf of California by $\sim 4-5 \mathrm{Ma}$

378 (Winker and Kidwell, 1986; Dorsey et al., 2007; Spencer et al., 2013; Crossey et al. 2015;

379 Howard et al., 2015). Based on this chronology, speciation leading to the Delta endemics

380 presumably followed the establishment of the Delta habitats around this time (Swift et al., 2011;

381 Ellingson, 2012).

382

383 Selection and Ecological Speciation in Response to Salinity Conditions

384 The parapatric distribution of Colpichthys in the Northern Gulf suggests that the two

385 species may have diverged due to ecological differentiation reinforced by divergent selection on

386 local adaptations. The divergence is likely linked to the gradient in salinity in the Northern Gulf.

387 While virtually no physiological data exists for $C$. hubbsi, C. regis is known to tolerate

388 hypersaline conditions as it is frequently observed in lagoons with salinity values reaching 50

389 psu (Castro-Aguirre and Espinosa-Pérez, 2006). Prior to the completion of Hoover Dam in 1935,

390 the water output at the Delta was estimated to be 16 to 18 billion cubic meters per year (Stockton

391 and Jacoby 1976), supporting a substantial historic fresh to salt water gradient through much of

392 the Delta. Development of an inverse hypersaline estuary followed in the 20th Century

393 damming and water removal from the system (Levín and Sánchez 1999). Although we are not

394 aware of any studies of salinity tolerance in captivity for Colpichthys, as noted above, silversides

395 have developed ecological species in response to salinity gradients in Brazil and Australia, the 
396 Mediterranean and the Eastern US (Bamber and Henderson, 1988; Beheregaray and Sunnucks,

397 2001; Fluker et al., 2011; Johnson et al., 1994; Klossa-Kilia et al., 2007; Francisco et al., 2006;

398 Olsen et al., 2016; Trabelsi et al., 2002). Thus, it is likely that historic salinity gradients in the

399 Delta played a role in reproductive isolation between the Colpichthys sister species. Moreover,

400 selection maintaining these species is prone to breakdown following the loss of freshwater.

401 Due to the difference in density of fresh and saltwater, salinity is known to influence the

402 morphology of the gas bladder, which maintains neutral buoyancy in teleost fishes. Among its

403 closest relatives in Atherinopsinae, C. hubbsi is the only species where the gas bladder does not

404 extend posterior to the visceral cavity (Crabtree, 1989), suggesting that salinity related selection

405 impacts the species. Other potential selective factors may involve the unusual silty conditions

406 and tides in the Delta and the limited depth in the Delta. Relative to other examples of species

407 boundaries particularly maintained by selection and differences in salinity in fishes such as those

408 associated with the transition into the Baltic, which developed during the Holocene (Barrio et al.,

409 2016); or those in Brazilian coastal silversides where divergence of freshwater forms was in the

410 Pleistocene (Beheregaray et al., 2002), our inferred early Pliocene timing of speciation based on

411 sequence differences between $C$. regis and $C$. hubbsi is substantially more ancient.

412

413 Evolutionary Implications of introgression for Colpichthys

414 Introgressive hybridization potentially has a number of distinct causes, including

415 anthropogenic introduction and habitat modification. It also has a number of different

416 evolutionary outcomes ranging from sharing of advantageous alleles between species (Martin et

417 al., 2006; Whitney et al., 2010; Pardo-Diaz et al., 2012; Hedrick, 2003) to extinction (Rhymer

418 and Simberloff, 1996; Todesco et al., 2016). Of particular interest here are examples of habitat 
419 alteration that lead to "speciation reversal", or the introgressive loss of ecological speciation.

420 Eutrophication, for example, has led to numerous examples of species loss in fishes (Vonlanthen

421 et al., 2012; Seehausen et al., 1997). Given that salinity is associated with ecological species in a

422 number of silversides, and the loss of freshwater in the Colorado Delta, introgression into the

423 more freshwater adapted C. hubbsi from the marine adapted C. regis would be expected.

424 Ultimately, introgression of $C$. regis alleles adapted for higher salinity could leave C. hubbsi at

425 risk of genetic swamping. In the long run, the risk of extinction by speciation reversal for $C$.

$426 h u b b s i$ will depend on the extent to which the loss of salinity gradient has eliminated the habitat

427 distinction in the Northern Gulf. While this study only identified backcrossed hybrids based on

428 the limited genetic loci sampled, it is possible that many of the morphological "pure bred" $C$.

429 hubbsi are in fact "cryptic" hybrids. Depending on the frequency and relative abundance of such

430 "cryptic" hybrids, interspecific gene flow may be more pervasive than suggested by our data. To

431 assess whether "speciation reversal" could pose a threat to $C$. hubbsi, future whole-genome

432 analyses will be required to quantify the amount of genomic introgression as well as identify loci

433 that may remain under divergent selection in the face of gene flow.

Demographic expansions

436 Given the geographic restriction of $C$. hubbsi, one immediate concern is whether the

437 reduced Colorado River outflow has directly contributed to a population decline. The rise in

438 salinity at the Delta has been implicated in the local decline of the clams in the genus Mulinia

439 (Rodriguez et al., 2001). Based on our results from neutrality tests and mismatch analyses, we

440 find significant departure from neutrality, but no evidence to support a recent bottleneck in $C$.

441 hubbsi. On the other hand, contrary to initial expectation, C. regis exhibits surprisingly low 
442 genetic diversity compared to its geographically restricted congener. This pattern is seen in all

443 three types of molecular markers (Cyt b: Fig. 4; RAG1: Table 3; microsatellites: Table S2). The

444 results from this study are consistent with demographic expansions in the recent past. Other

445 factors, such as selective sweep or fine-scaled population structure (Ptak and Przeworski, 2002),

446 could produce similar mtDNA patterns, but these mechanisms seem unlikely to have generated

447 the similar patterns of diversity in all 3 data sets. We offer the following scenario as a possible

448 explanation for the observed data. In the mismatch analysis, the model parameter $\tau$ estimates the

449 age of demographic expansion. Based on this, our results (Table 6) suggest that C. hubbsi may

450 have attained larger populations in the Delta estuarine habitats than C. regis and that C. hubbsi

451 populations were either more continuous or experienced a more ancient expansion relative to $C$.

452 regis. One possible explanation for this could come from Pleistocene climate and sea-level

453 fluctuations. Recent work (Dolby et al. 2016) demonstrated that interactions between coastal

454 geomorphology and Pleistocene sea-level fluctuations limited estuary habitats to refugia during

455 glacial sea-level minima, impacting modern population structures of estuarine fish. In addition,

456 during the Pleistocene, wetter climates increased Colorado River outflow into the Gulf, while the

457 gentle sloping bathymetry of the Northern Gulf together with the lowering of sea-level likely

458 expanded habitats for $C$. hubbsi much further south, allowing for population growth. Meanwhile,

459 the steeper outer shelves on both sides Gulf to the south could have restricted suitable refugial

460 habitats for C. regis during sea-level lowstand (Dolby, 2015). The lack of genetic diversity in $C$.

461 regis populations may represent rapid range expansion from these limited refugia following sea-

462 level rise at the end of the Pleistocene. Crucial to this hypothesis is the precise timing of the

463 demographic and range expansions. More complete sampling of C. regis within each of the 
464 modern localities or genomic approaches are needed in future studies to further explore this 465 issue.

466

467

468

469

470

471

472

473

474

475

476

478

479

480

481

482

483

484

485

486

\section{Potential implications for Delta endemics}

Of the numerous Gulf endemics (Palacios-Salgado et al., 2012), some are confined to the northernmost Gulf, and a smaller subset are very locally endemic to the Delta itself, which is an area protected as a Biosphere Reserve (Reservade la Biosfera del Alto Golfo de California y Delta del Rio Colorado). Of these northernmost endemics, some are relicts of broader distributions, while others appear to be ecological species that evolved in association with the Colorado Delta (Jacobs et al. 2004). Apparent relictual species include the critically endangered Vaquita, the world's smallest cetacean, whose closest relative is found on the coasts of South America south of Peru (Munguia-Vega et al., 2007). The totoaba (Totoaba macdonaldi) was historically an important fishery resource that appears to have depended on freshwater input from the Colorado River for rapid growth early in development (Rowell et al., 2008). This genus, broadly endemic to the Gulf, is known from fossils in the Miocene of California Central Valley (Huddleston \& Takeuchi, 2007); its closest relatives are in the Atlantic and IndoPacific (Lo et al., 2015). In addition to these relicts which may have been directly impacted by salinity changes or other anthropogenic activities such as overfishing, three taxa in the region appear to have evolved ecological species pairs associated with the Delta. Apart from the fish genera Colpichthys and Gillichthys as discussed above, the fiddler Crab Uca monilifera and U. princeps conform to the same pattern (Brusca, 1980). Thus, out of a suite of five northernmost Gulf endemic estuarine species, three are potentially at risk of introgression due to hydrologic modification. While a number of studies have argued that the northern Gulf fauna has been 
487 directly impacted by salinity (Rodriguez et al., 2001; Rowell et al., 2008), others have

488 emphasized the minimal change in Northern Gulf biological productivity associated with the

489 anthropogenic loss of freshwater input from the Colorado River (Brusca et al., 2017). However,

490 there may nevertheless be strong impacts on the endemic diversity of this biologically unique

491 region, especially with regards to introgression in endemics specific to the Colorado Delta

492 proper.

493

494 Global Change Context

495 Early $20^{\text {th }}$ Century water removal tended to impact larger river systems primarily in semi-

496 arid settings, where freshwater is at a premium and where economic development is well

497 advanced; this is well exemplified by the Southwestern US. With increasing population growth

498 and economic development in a wider range of geographic settings, damming and diversion

499 efforts have continued to expand from rivers that traverse arid regions, impacting the Deltas

500 estuaries of rivers such as the Nile (Stanley \& Warme 1998) and the Euphrates (Isaev \&

501 Mikhailova 2009), to many of the largest river systems of Asia, such as the Mekong (Kondolf et

502 al. 20014). Despite this, the impact on estuarine diversity, especially as regards to the potential

503 loss of diversity due to introgression between ecological species, has not been widely discussed

504 or assessed. In the case of the Colorado River Delta, we have been able to establish that

505 introgression is ongoing in the context of the ecologically altered Delta environment. This is the

506 first step in establishing the risk of introgressive species loss in river estuaries that have suffered

507 from water extraction and loss of freshwater input. This is yet another factor in a long list of

508 ecological and biodiversity impacts consequent to altering riverine hydrologic processes, and 
509 should be systematically considered in a global context so that the full ecological consequences

510 and diversity costs of such development can be properly understood.

511

512 CONCLUSION

We document the Pliocene separation and recent introgression between a sister species

514 pair in the northern Gulf of California. Our evidence supports hybridization and introgression

515 into the IUCN endangered Delta endemic Colpichthys hubbsi from the more widespread Gulf

516 species $C$. regis following $20^{\text {th }}$ century environmental alteration through water removal and

517 salinity change in the Delta system. The work combines multiple lines of phenotypic and genetic

518 evidence to demonstrate this directional introgressive hybridization. We find no evidence for

519 population decline in $C$. hubbsi, yet continued introgression may jeopardize the genetic integrity

520 of this taxon. Genetic diversity of $C$. regis is revealed to be lower than expected for a healthy,

521 widely distributed species so it likely merits its IUCN threatened designation. Our work

522 highlights the need for closer monitoring and further demographic investigations of Colpichthys

523 populations not just within the Delta but also throughout the Northern Gulf. More generally, our

524 work implies that other Colorado Delta-specific endemics such as the goby Gillichthys detrusus

525 and the fiddler crab Uca monilifera may also be ecological species at risk of loss through

526 introgression from their proximally distributed congeners. More broadly, a general suite of

527 ecological species around the world that evolved in response to salinity gradients in major river

528 systems are likely at increasing risk of introgressive extinction as water extraction and climate

529 change impacts accelerate in river systems globally.

530

531 ACKNOWLEDGEMENTS 
533 Richmond for feedback and comments; Rick Feeney of the Los Angeles County Natural History

534 Museum for access to an X-ray machine and the specimens in the ichthyology collection; H.J.

535 Walker and Phil Hastings of the Scripps Institution of Oceanography for providing the historical

536 specimens; Greer Dolby and Ryan Ellingson for advice on data analysis; Bruno Passerelli for

537 assistance in data collection; Lloyd Findley for facilitating permitting and collection. Assistance

538 with field sampling was provided by T. Baumiller, V. Cassano, R. Ellingson, R. Hechinger, F.

539 Hertel, J. Lorda, and D. Yuan.

\section{Literature Cited}

542

Akihito, Iwata A, Kobayashi T, Ikeo K, Imanishi T, Ono H, Umehara Y, Hamamatsu C, Sugiyama K, Ikeda Y, Sakamoto K (2000) Evolutionary aspects of gobioid fishes based upon a phylogenetic analysis of mitochondrial cytochrome $b$ genes. Gene, 259, 5-15.

Bamber R, Henderson P (1988) Pre-adaptive plasticity in atherinids and the estuarine seat of teleost evolution. Journal of Fish Biology, 33, 17-23.

Barrio AM, Lamichhaney S, Fan G, Rafati N, Pettersson M, Zhang H, Dainat J, Ekman D, Höppner M, Jern P, Martin M, Nystedt B, Liu X, Chen W, Liang X, Shi C, Fu Y, Ma K, Zhan X, Feng C, Gustafson U, Rubin C-J, Almén MS, Blass M, Casini M, Folkvord A, Laikre L, Ryman $\mathrm{N}$, Lee SM-Y, Xu X, Andersson Leif (2016) The genetic basis for ecological adaptation of the Atlantic herring revealed by genome sequencing. Elife, 5, e12081.

552 Beheregaray LB, Sunnucks P (2000) Microsatellite loci isolated from Odontesthes argentinensis 553 and the $O$. perugiae species group and their use in other South American silverside fish.

554 Molecular Ecology, 9, 629-631.

555 Beheregaray LB, Sunnucks P (2001) Fine-scale genetic structure, estuarine colonization and 556 incipient speciation in the marine silverside fish Odontesthes argentinensis. Molecular Ecology, 557 10, 2849-2866.

Beheregaray LB, Sunnucks P, Briscoe DA (2002) A rapid fish radiation associated with the last sea-level changes in southern Brazil: The silverside Odontesthes perugiae complex. Proceedings of the Royal Society of London B: Biological Sciences, 269, 65-73.

561 Bonetto A, Wais J, Castello H (1989) The increasing damming of the Paraná basin and its effects 562 on the lower reaches. River Research and Applications, 4, 333-346. 
563 Boutin-Ganache I, Raposo M, Raymond M, Deschepper CF (2001) M13-tailed primers improve

564 the readability and usability of microsatellite analyses performed with two different allele-sizing

565 methods. Biotechniques, 31, 24-6.

566 Brusca RC (1980) Common intertidal invertebrates of the Gulf of California. Univ of Arizona

567 Pr.

568 Brusca RC, Álvarez-Borrego S, Hastings PA, Findley LT (2017) Colorado river flow and 569 biological productivity in the northern Gulf of California, Mexico. Earth-Science Reviews, 164, $5701-30$.

571 Byrne RJ, Avise JC (2009) Multiple paternity and extra-group fertilizations in a natural 572 population of California grunion (Leuresthes tenuis), a beach-spawning marine fish. Marine

573 Biology, 156, 1681-1690.

574 Carriquiry J, Sánchez A (1999) Sedimentation in the Colorado River Delta and upper Gulf of

575 California after nearly a century of discharge loss. Marine Geology, 158, 125-145.

576 Castro-Aguirre JL, Espinosa Pérez H (2006) Los peces de la familia Atherinopsidae (Teleostei:

577 Atheriniformes) de las lagunas costeras neutras e hipersalinas de México. Hidrobiológica, 16,

578 89-101.

579 Crabtree CB (1989) A new silverside of the genus Colpichthys (Atheriniformes: Atherinidae)

580 from the Gulf of California, Mexico. Copeia, 1989, 558-568.

581 Crossey LC, Karlstrom KE, Dorsey R, Pearce J, Wan E, Beard LS, Asmerom Y, Polyak V, Crow 582 RS, Cohen A, Bright J, Pecha ME (2015) Importance of groundwater in propagating downward 583 integration of the 6-5 Ma Colorado River system: Geochemistry of springs, travertines, and

584 lacustrine carbonates of the Grand Canyon region over the past 12 Ma. Geosphere, 11, 660-682.

585 Dolby, GA (2015) Physical drivers of spatiotemporal genetic patterns and evolutionary

586 processes among and within species of the North American southwest. PhD dissertation.

587 University of California, Los Angeles.

588 Dolby GA, Hechinger R, Ellingson RA, Findley LT, Lorda J, Jacobs DK (2016) Sea-level driven 589 glacial-age refugia and post-glacial mixing on subtropical coasts, a palaeohabitat and genetic 590 study. Proceedings of the Royal Society of London B: Biological Sciences, 283.

591 Dorsey RJ, Fluette A, McDougall K, Housen BA, Janecke SU, Axen GJ, Shirvell CR (2007)

592 Chronology of Miocene-Pliocene deposits at Split Mountain Gorge, Southern California: A

593 record of regional tectonics and Colorado River evolution. Geology, 35, 57.

594 Drummond A, Ashton B, Buxton S, Cheung M, Cooper A, Duran C, Field M, Heled J, Kearse

595 M, Markowitz S, Moir R (2011) Geneious pro v5.5.6. available from http://www.geneious.com/.

596 Earl DA (2012) STRUCTURE harvester: A website and program for visualizing structure output 597 and implementing the Evanno method. Conservation genetics resources, 4, 359-361. 
598 Ellingson R (2012) Phylogenetics and phylogeography of north Pacific bay gobies: Adaptive 599 convergence, relictual endemism, and climate-driven population structure. $\mathrm{PhD}$ dissertation.

600 University of California, Los Angeles.

601 Evanno G, Regnaut S, Goudet J (2005) Detecting the number of clusters of individuals using the 602 software structure: A simulation study. Molecular ecology, 14, 2611-2620.

603 Excoffier L, Laval G, Schneider S (2005) Arlequin (version 3.0): An integrated software package 604 for population genetics data analysis. Evolutionary bioinformatics, 1.

605 Falush D, Stephens M, Pritchard JK (2003) Inference of population structure using multilocus 606 genotype data: Linked loci and correlated allele frequencies. Genetics, 164, 1567-1587.

607 Findley L, Collette B, Espinosa H (2010a) Colpichthys hubbsi. The IUCN Red List of Threatened 608 Species 2010: e.T183457A8116697.

609 Findley L, Collette B, Espinosa H (2010b) Colpichthys regis. The IUCN Red List of Threatened 610 Species 2010: e.T183357A8099025.

611 Fluker BL, Pezold F, Minton RL (2011) Molecular and morphological divergence in the inland 612 silverside (Menidia beryllina) along a freshwater-estuarine interface. Environmental biology of 613 fishes, 91, 311.

614 Francisco SM, Cabral H, Vieira MN, Almada VC (2006) Contrasts in genetic structure and 615 historical demography of marine and riverine populations of Atherina at similar geographical 616 scales. Estuarine, Coastal and Shelf Science, 69, 655-661.

617 Fu Y-X (1997) Statistical tests of neutrality of mutations against population growth, hitchhiking 618 and background selection. Genetics, 147, 915-925.

619 Fu Y-X, Li W-H (1993) Statistical tests of neutrality of mutations. Genetics, 133, 693-709.

620 Glenn EP, Lee C, Felger R, Zengel S (1996) Effects of water management on the wetlands of the 621 Colorado River Delta, Mexico., 10, 1175-1186.

622 Harrison RG, Larson EL (2014) Hybridization, introgression, and the nature of species

623 boundaries. Journal of Heredity, 105, 795-809.

624 Hastings PA, Findley LT (2007) Marine fishes of the upper gulf biosphere reserve, northern Gulf 625 of California. Dry borders, great natural reserves of the Sonoran Desert, R. Felger y B. Broyles 626 (eds.). University of Utah Press, Salt Lake City, 364-382.

627 Hedrick PW (2013) Adaptive introgression in animals: Examples and comparison to new 628 mutation and standing variation as sources of adaptive variation. Molecular ecology, 22, 46066294618.

630 Heiser CB (1973) Introgression re-examined. The Botanical Review, 39, 347-366.

631 Howard KA, House PK, Dorsey RJ, Pearthree PA (2015) River-evolution and tectonic 632 implications of a major Pliocene aggradation on the lower Colorado river: The bullhead 633 alluvium. Geosphere, 11, 1-30. 
634 Hubbs CL, Lagler KF, Smith GR, others (2004) Fishes of the great lakes region. University of 635 Michigan.

636 Hubisz MJ, Falush D, Stephens M, Pritchard JK (2009) Inferring weak population structure with 637 the assistance of sample group information. Molecular ecology resources, 9, 1322-32.

638 Huddleston RW, Takeuchi GT (2007) First fossil record of Totoaba villamar 1980 (Teleostei: 639 Sciaenidae) based upon early Miocene otoliths from California with comments on the ontogeny 640 of the saccular otolith. Bulletin, Southern California Academy of Sciences, 106, 1-15.

641 Isaev VA, Mikhailova MV (2009) The Hydrography, Evolution, and Hydrological Regime of the 642 Mouth Area of the Shatt Al-Arab River. Water Resources, 36, 380-395.

643 Jacobs DK, Haney TA, Louie KD (2004) Genes, diversity, and geologic process on the Pacific 644 coast. Annu. Rev. Earth Planet. Sci., 32, 601-652.

645 Jakobsson M, Rosenberg NA (2007) CLUMPP: A cluster matching and permutation program for 646 dealing with label switching and multimodality in analysis of population structure.

647 Bioinformatics, 23, 1801-1806.

648 Jenkins OP, Evermann BW (1889) Description of eighteen new species of fishes from the Gulf 649 of California.

650 Johnson M, Watts R, Black R (1994) High levels of genetic subdivision in peripherally isolated populations of the Atherinid fish Craterocephalus capreoli in the Houtman Abrolhos islands,

652 western Australia. Marine Biology, 119, 179-184.

Jombart T, Ahmed I (2011) Adegenet 1.3-1: New tools for the analysis of genome-wide SNP data. Bioinformatics, 27, 3070-3071.

Klossa-Kilia E, Papasotiropoulos V, Tryfonopoulos G, Alahiotis S, Kilias G (2007) Phylogenetic relationships of Atherina hepsetus and Atherina boyeri (pisces: Atherinidae) populations from

657 Greece, based on mtDNA sequences. Biological journal of the Linnean Society, 92, 151-161.

658 Kondolf, G. M., Rubin, Z. K., \& Minear, J. T. (2014). Dams on the Mekong: cumulative 659 sediment starvation. Water Resources Research, 50(6), 5158-5169.

660

661

Kumar S, Stecher G, Tamura K (2016) MEGA7: Molecular evolutionary genetics analysis

662

663

664 Lavin M, Sánchez S (1999) On how the Colorado River affected the hydrography of the upper 665 Gulf of California. Continental Shelf Research, 19, 1545-1560.

666 Lee CE (2016) Evolutionary mechanisms of habitat invasions, using the copepod Eurytemora 667 affinis as a model system. Evolutionary applications, 9, 248-270.

668 Leigh JW, Bryant D (2015) Popart: Full-feature software for haplotype network construction. 669 Methods in Ecology and Evolution, 6, 1110-1116. 
670 Librado P, Rozas J (2009) DnaSP v5: A software for comprehensive analysis of DNA

671 polymorphism data. Bioinformatics, 25, 1451-1452.

672 Liermann CR, Nilsson C, Robertson J, Ng RY (2012) Implications of dam obstruction for global 673 freshwater fish diversity. BioScience, 62, 539-548.

674 Lo P-C, Liu S-H, Chao NL, Nunoo FKE, Mok H-K, Chen W-J (2015) A multi-gene dataset 675 reveals a tropical new world origin and early Miocene diversification of croakers (Perciformes:

676 Sciaenidae). Molecular phylogenetics and evolution, 88, 132-143.

677 Lu XX, Siew RY (2006) Water discharge and sediment flux changes over the past decades in the 678 Lower Mekong River: possible impacts of the Chinese dams. Hydrology and Earth System

679 Sciences Discussions, 10, 181-195.

680 Martin NH, Bouck AC, Arnold ML (2006) Detecting adaptive trait introgression between Iris 681 fulva and I. brevicaulis in highly selective field conditions. Genetics, 172, 2481-2489.

682 McDougall K, Martínez AYM (2014) Evidence for a marine incursion along the lower Colorado 683 River corridor. Geosphere, 10, 842-869.

684 Munguia-Vega A, Esquer-Garrigos Y, Rojas-Bracho L, Vazquez-Juarez R, Castro-Prieto A, 685 Flores-Ramirez S (2007) Genetic drift vs. natural selection in a long-term small isolated 686 population: Major histocompatibility complex class II variation in the Gulf of California endemic 687 porpoise (Phocoena sinus). Molecular ecology, 16, 4051-4065.

688 Nilsson C, Berggren K (2000) Alterations of riparian ecosystems caused by river regulation: dam 689 operations have caused global-scale ecological changes in riparian ecosystems. how to protect 690 river environments and human needs of rivers remains one of the most important questions of 691 our time. BioScience, 50, 783-792.

692 Nilsson C, Reidy CA, Dynesius M, Revenga C (2005) Fragmentation and flow regulation of the 693 world's large river systems. Science, 308, 405-408.

694 Olsen Z, Anderson J, McDonald D (2016) Morphological and molecular variation among 695 populations of tidewater (Menidia peninsulae) and inland (M. beryllina) silversides: Insight into 696 drivers of adaptation and speciation of silverside fishes. Environmental Biology of Fishes, 99, $697857-871$.

698 Palacios-Salgado DS, Burnes-Romo LA, Tavera JJ, Ramírez-Valdez A (2012) Endemic fishes of 699 the Cortez biogeographic province (Eastern Pacific Ocean). Acta Ichthyologica et Piscatoria, 42, $700 \quad 153-164$.

701 Pardo-Diaz C, Salazar C, Baxter SW, Merot C, Figueiredo-Ready W, Joron M, McMillan WO, 702 Jiggins CD (2012) Adaptive introgression across species boundaries in Heliconius Butterflies (M 703 R. Kronforst, Ed,). PLoS Genetics, 8, e1002752.

704 Poulson SR, John BE (2003) Stable isotope and trace element geochemistry of the basal Bouse 705 Formation carbonate, southwestern United States: Implications for the Pliocene uplift history of 706 the Colorado Plateau. Bulletin of the Geological Society of America, 115, 434-444. 
707 Pritchard JK, Stephens M, Donnelly P (2000) Inference of population structure using multilocus 708 genotype data. Genetics, 155, 945-959.

709 Ptak SE, Przeworski M (2002) Evidence for population growth in humans is confounded by fine710 scale population structure. Trends in Genetics, 18, 559-563.

711 Ramos-onsins SE, Rozas J (2006) Statistical Properties of New Neutrality Tests Against

712 Population Growth. Molecular Biology and Evolution, 23, 1642-1642.

713 Rhymer JM, Simberloff D (1996) Extinction by hybridization and introgression. Annual Review 714 of Ecology and Systematics, 27, 83-109.

715 Rodriguez C, Flessa K, Dettman D (2001) Effects of upstream diversion of Colorado River water 716 on the estuarine bivalve mollusc Mulinia coloradoensis. Conservation Biology, 15, 249-258.

717 Rogers AR, Harpending H (1992) Population growth makes waves in the distribution of pairwise 718 genetic differences. Molecular Biology and Evolution, 9, 552-569.

719 Rosenberg NA (2004) DISTRUCT: A program for the graphical display of population structure. 720 Molecular Ecology Notes, 4, 137-138.

721 Roskowski JA, Patchett PJ, Spencer JE, Pearthree PA, Dettman DL, Faulds JE, Reynolds AC 722 (2010) A late Miocene-early Pliocene chain of lakes fed by the Colorado River: Evidence from $723 \mathrm{Sr}, \mathrm{C}$, and $\mathrm{O}$ isotopes of the Bouse Formation and related units between Grand Canyon and the

724 Gulf of California. Geological Society of America Bulletin, 122, 1625-1636.

725 Rowell K, Flessa KW, Dettman DL, Román MJ, Gerber LR, Findley LT (2008) Diverting the 726 Colorado River leads to a dramatic life history shift in an endangered marine fish. Biological 727 Conservation, 141, 1138-1148.

728 Seehausen O, Van Alphen JJ, Witte F (1997) Cichlid fish diversity threatened by eutrophication 729 that curbs sexual selection. Science, 277, 1808-1811.

730 Spencer JE, Patchett PJ (1997) Sr isotope evidence for a lacustrine origin for the upper Miocene 731 to Pliocene Bouse formation, lower Colorado River trough, and implications for timing of 732 Colorado Plateau uplift. Geological Society of America Bulletin, 109, 767-778.

733 Spencer JE, Patchett PJ, Pearthree PA, House PK, Sarna-Wojcicki AMS, Wan E, Roskowski JA, 734 Faulds JE (2013) Review and analysis of the age and origin of the Pliocene Bouse Formation,

735 lower Colorado River Valley, southwestern USA. Geosphere, 9, 444-459.

736 Stanley DJ, Warne AG (1998). Nile Delta in its destruction phase. Journal of Coastal Research, 737 1998, 795-825

738

739

740

741

Stockton CW, Jacoby Jr. GC (1976) Long-term surface-water supply and streamflow trends in the upper Colorado River basin based on tree-ring analyses. Natl. Sci. Found. Lake Powell Res. Proj. Bull, 18, 70. 
742 Swift CC, Findley LT, Ellingson RA, Flessa KW, Jacobs DK (2011) The delta mudsucker,

743 Gillichthys detrusus, a valid species (Teleostei: Gobiidae) endemic to the Colorado River Delta,

744 northernmost Gulf of California, México. Copeia, 2011, 93-102.

745 Tajima F (1989) Statistical method for testing the neutral mutation hypothesis by DNA

746 polymorphism. Genetics, 123, 585-595.

747 Tamura K, Nei M (1993) Estimation of the number of nucleotide substitutions in the control

748 region of mitochondrial DNA in humans and chimpanzees. Molecular biology and evolution, 10,

$749 \quad 512-526$.

750 Tamura K, Battistuzzi FU, Billing-Ross P, Murillo O, Filipski A, Kumar S (2012) Estimating

751 divergence times in large molecular phylogenies. Proceedings of the National Academy of

752 Sciences, 109, 19333-19338.

753 Todd TN (1976) Pliocene occurrence of the recent Atherinid fish Colpichthys regis in Arizona.

754 Journal of Paleontology, 50(3), 462-466.

755 Todesco M, Pascual MA, Owens GL, Ostevik KL, Moyers BT, Hübner S, Heredia SM, Hahn

756 MA, Caseys C, Bock DG, Rieseberg LH (2016) Hybridization and extinction. Evolutionary

757 applications, 9, 892-908.

758 Trabelsi M, Gilles A, Fleury C, Mâamouri F, Quignard J-P, Faure É (2002) Atherina punctata

759 and Atherina lagunae (Pisces, Atherinidae), new species found in the Mediterranean Sea. Article

760 2: Molecular investigations of three Atherinid species. Comptes rendus biologies, 325, 1119

7611128.

762 Vähä JP, Primmer CR (2006) Efficiency of model-based Bayesian methods for detecting hybrid

763 individuals under different hybridization scenarios and with different numbers of loci. Molecular

764 Ecology, 15, 63-72.

765 Vonlanthen P, Bittner D, Hudson AG, Young KA, Müller R, Lundsgaard-Hansen B, Roy D, Di

766 Piazza S, Largiader CR, Seehausen O (2012) Eutrophication causes speciation reversal in

767 whitefish adaptive radiations. Nature, 482, 357-362.

768 Whitney KD, Randell RA, Rieseberg LH (2010) Adaptive introgression of abiotic tolerance traits 769 in the sunflower Helianthus annuиs. New Phytologist, 187, 230-239.

770 Winker CD, Kidwell SM (1986) Paleocurrent evidence for lateral displacement of the Pliocene

771 Colorado River Delta by the San Andreas Fault system, southeastern California. Geology, 14,

772788.

773 Wu DY, Ugozzoli L, Pal BK, Wallace RB (1989) Allele-specific enzymatic amplification of

774 beta-globin genomic DNA for diagnosis of sickle cell anemia. Proceedings of the National

775 Academy of Sciences of the United States of America, 86, 2757-2760.

776 Yang SL, Zhang J, Zhu J, Smith JP, Dai SB, Gao A, Li P (2005) Impact of dams on Yangtze

777 river sediment supply to the sea and delta intertidal wetland response. Journal of Geophysical

778 Research: Earth Surface, 110. 


\section{Figure 1}

Map and Phylogeography of Colpichthys

(A) Map of the coastline of the Gulf of California with sampling localities, color coded by species distribution. C. hubbsi native populations are colored blue; C. regis native populations are colored red; and populations where both species co-occur are colored magenta. Location codes are summarized in Table 1 and used in text throughout. (B) Time calibrated Maximum-Likelihood (ML) tree of cytochrome $b$ (872bp). Branch lengths (substitutions per site) are indicated below the branches. One specimen of Atherinops affinis was used as outgroup to root the tree. Branch labels show branch lengths (substitutions/site).
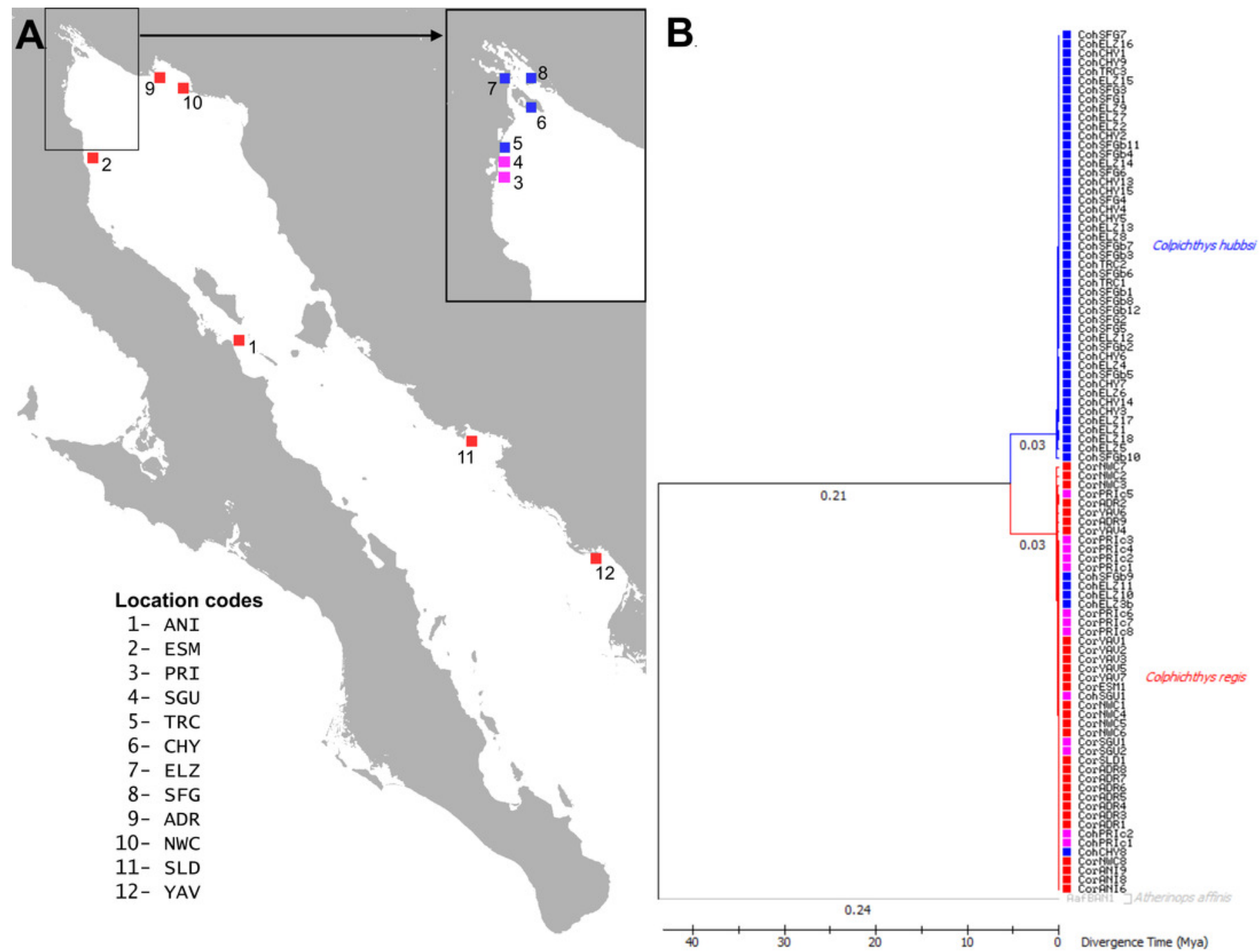


\section{Figure 2 (on next page)}

Dot plots of morphological data

Dot plots showing external ( $A$ and $C$ ) and vertebral ( $B$ and $D)$ morphological data; size of dots is proportional to the number of specimens (n). "Delta Edge" is the hypothesized hybrid zone; "Delta" is the territory for C. hubbsi; "Baja" and "Sonora" are the territories for $C$. regis. Refer to Table 1 and Table 2 for location codes of modern and historical specimens, respectively. Six specimens from NWC and three specimens from YAV were excluded from the hemal spine data set (D) as these specimens were too small to reliably identify the presence/absence of the expanded process on the hemal spines (See Fig. S1). 
A.

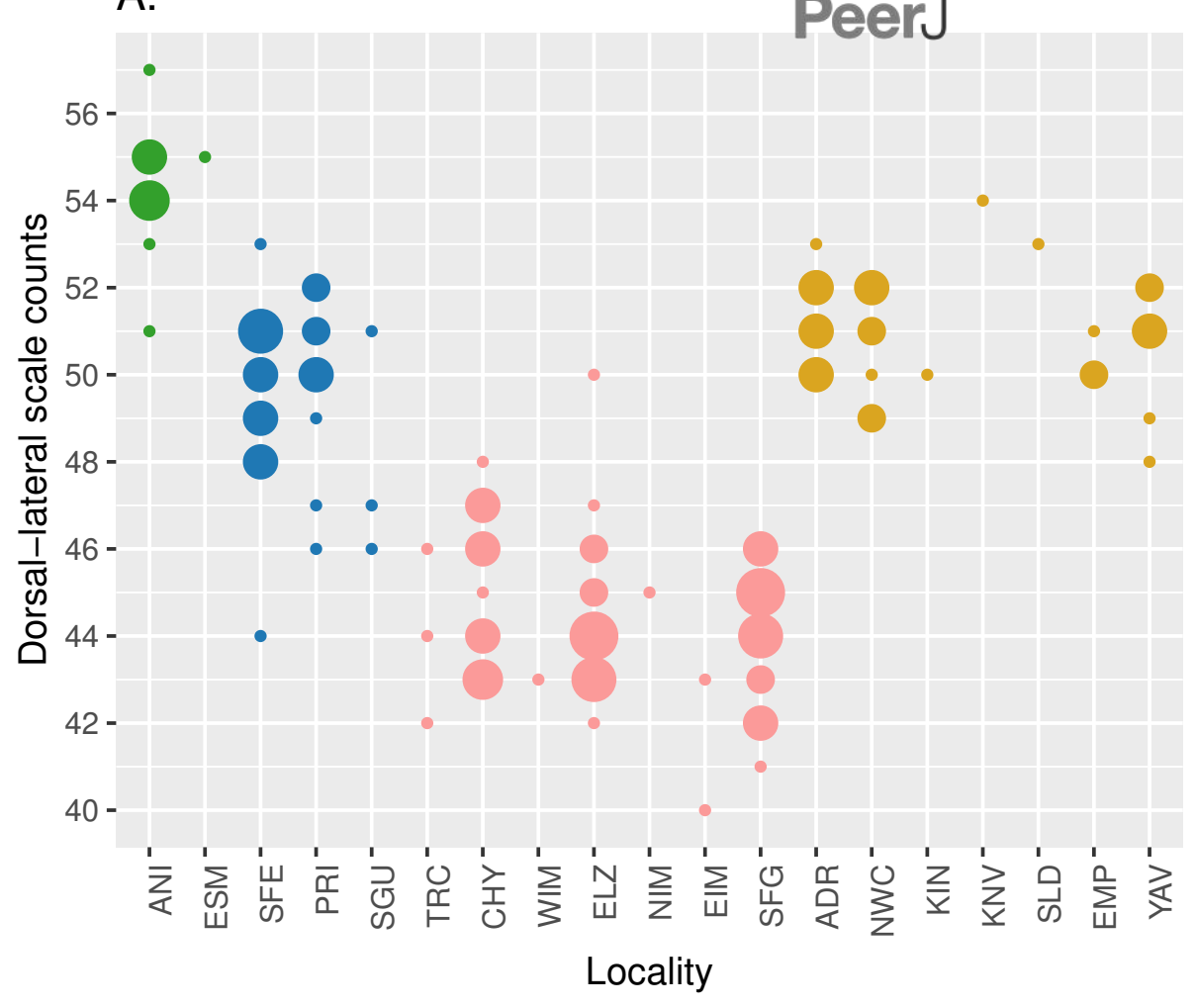

c.

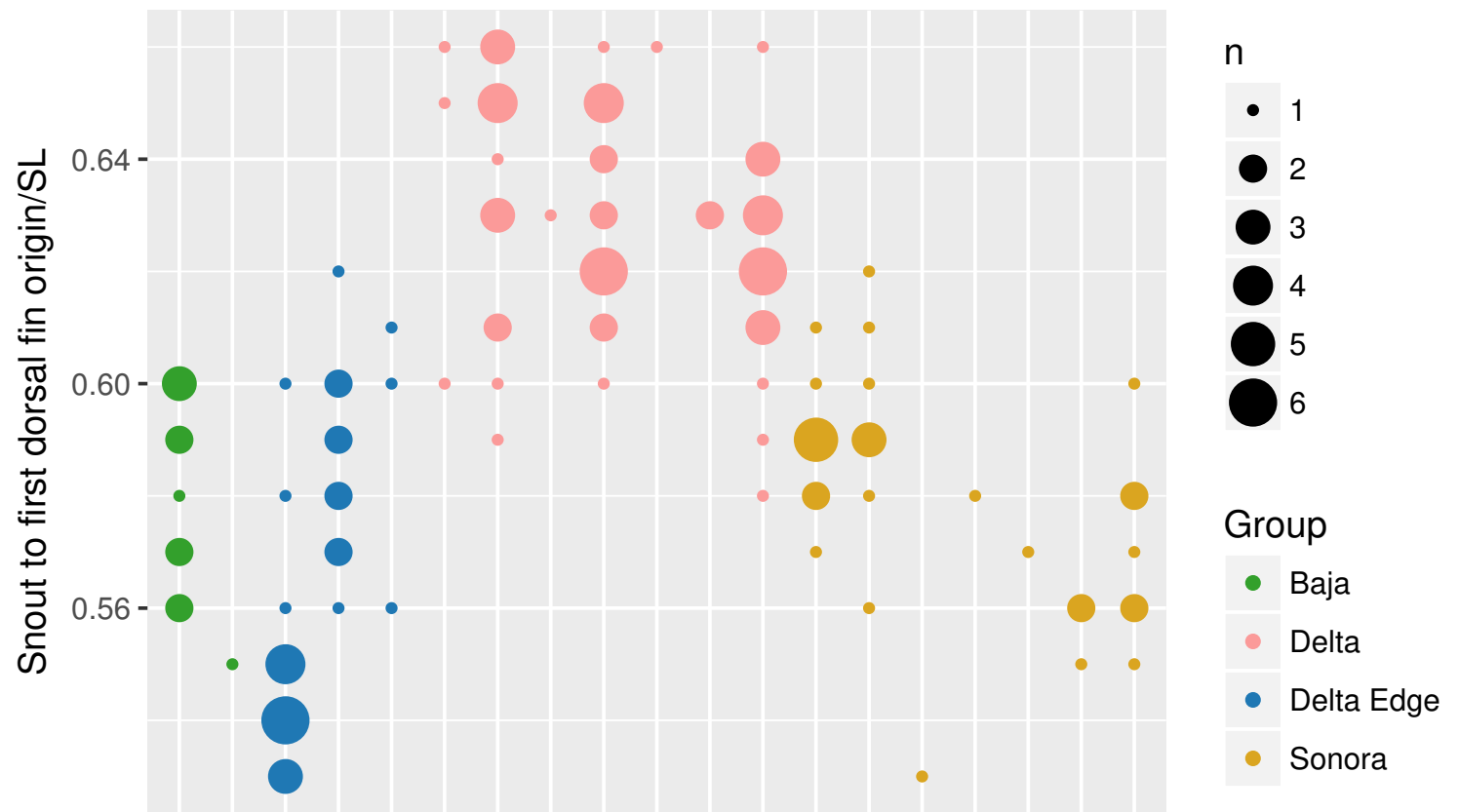

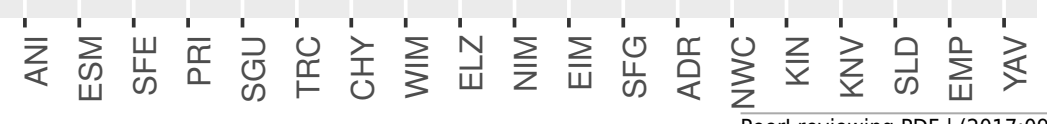

Locality

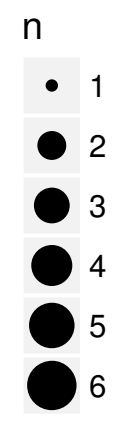

Group

- Baja

- Delta

- Delta Edge

- Sonora

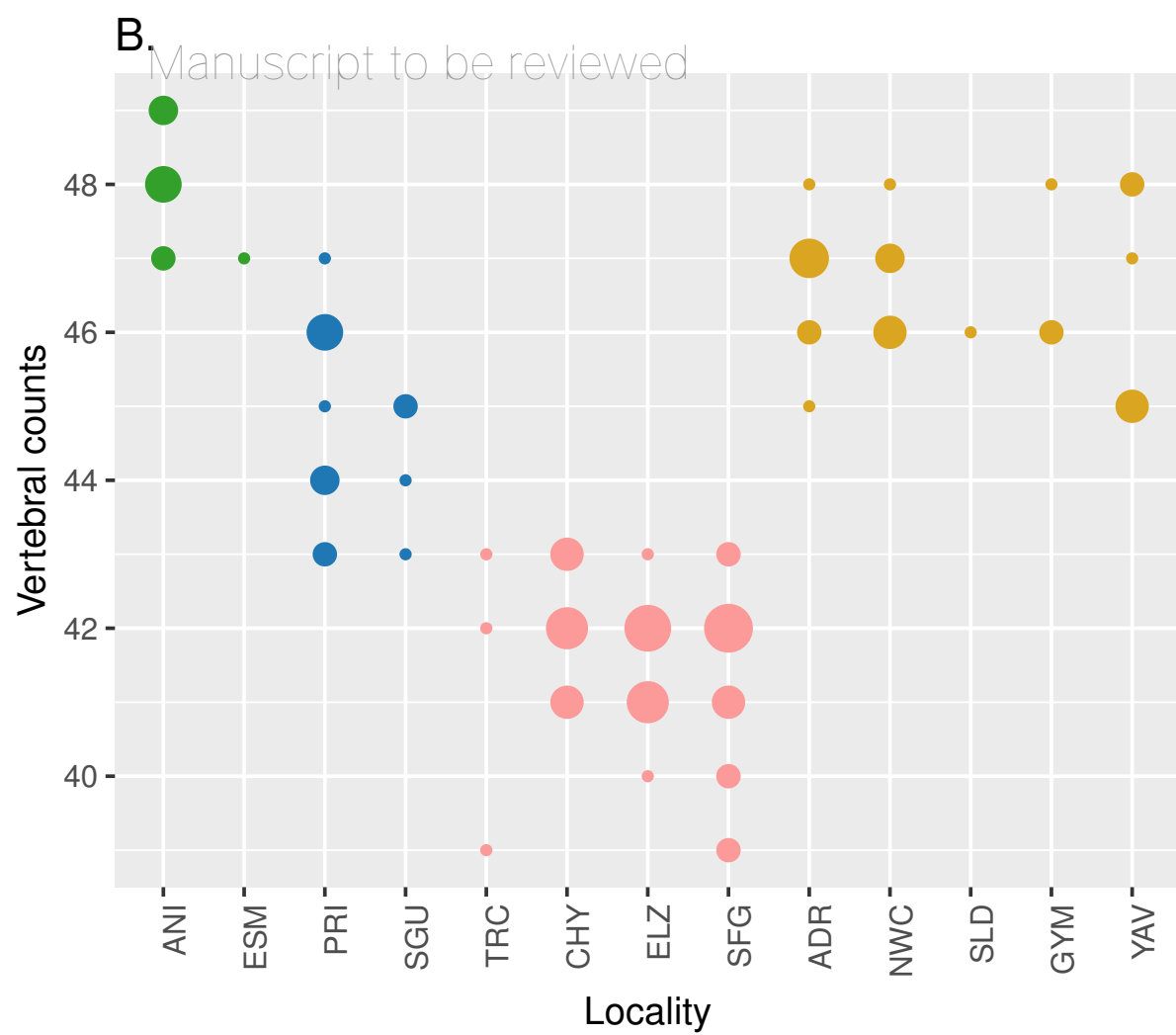

D.

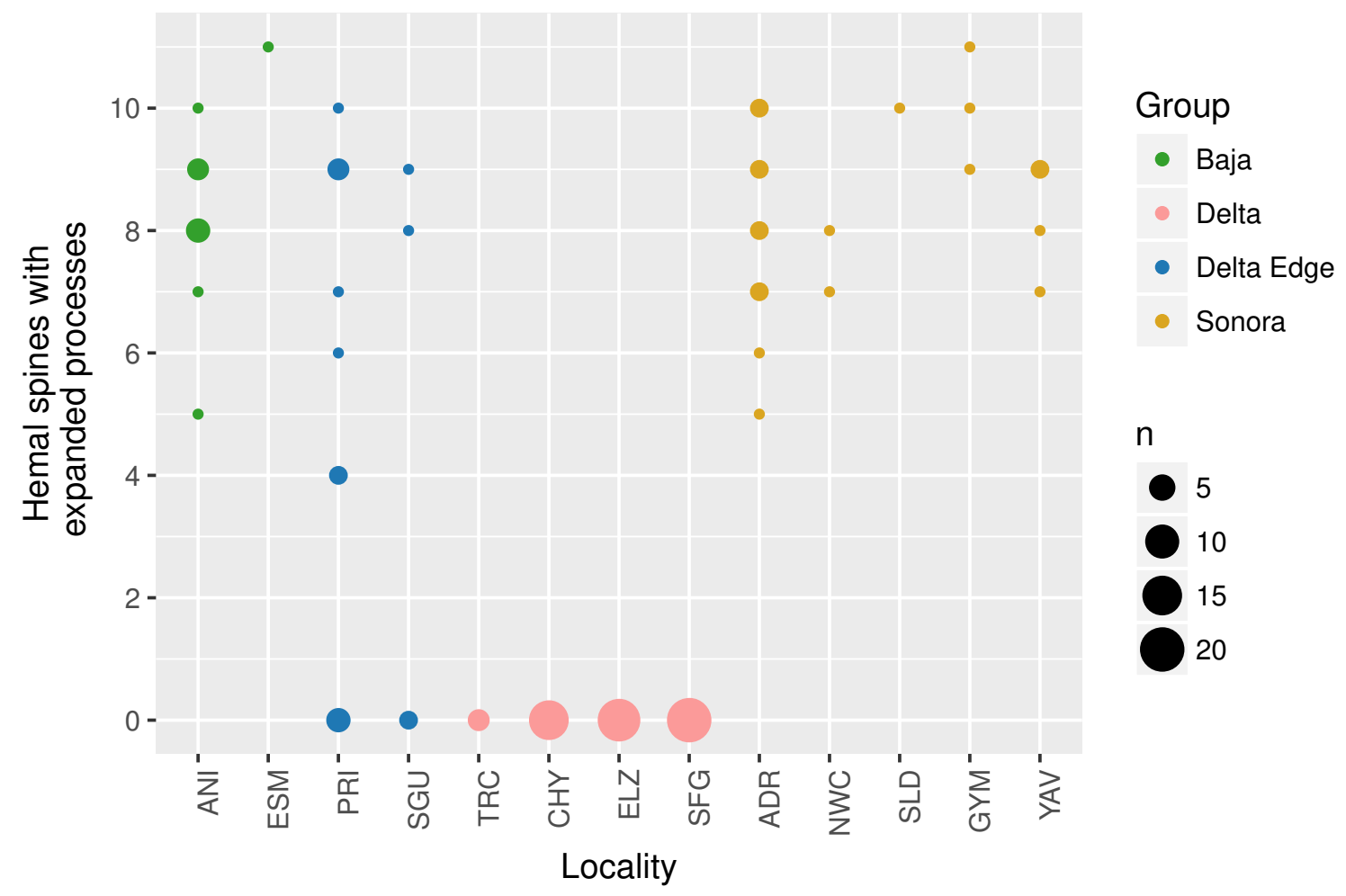

Group

- Baja

- Delta

- Delta Edge

- Sonora

$\mathrm{n}$

2.5

5.0

7.5

10.0
Group

Baja

Delta

Delta Edge

5

( 15 


\section{Figure 3}

STRUCTURE assignment of individuals to groups

STRUCTURE bar plots showing q-values of each individual in each sampling locale for $\mathrm{K}=2$.

Color for each bar represents admixture proportions of $C$. regis (red) and C. hubbsi (blue).

Correlated allele frequency model (A). Independent allele frequency model (B). Scatter plot of the first discriminant functions in the DAPC analyses based on phenotypic and microsatellite data (C). Histograms on the top and the right side show the distributions for each axis. 

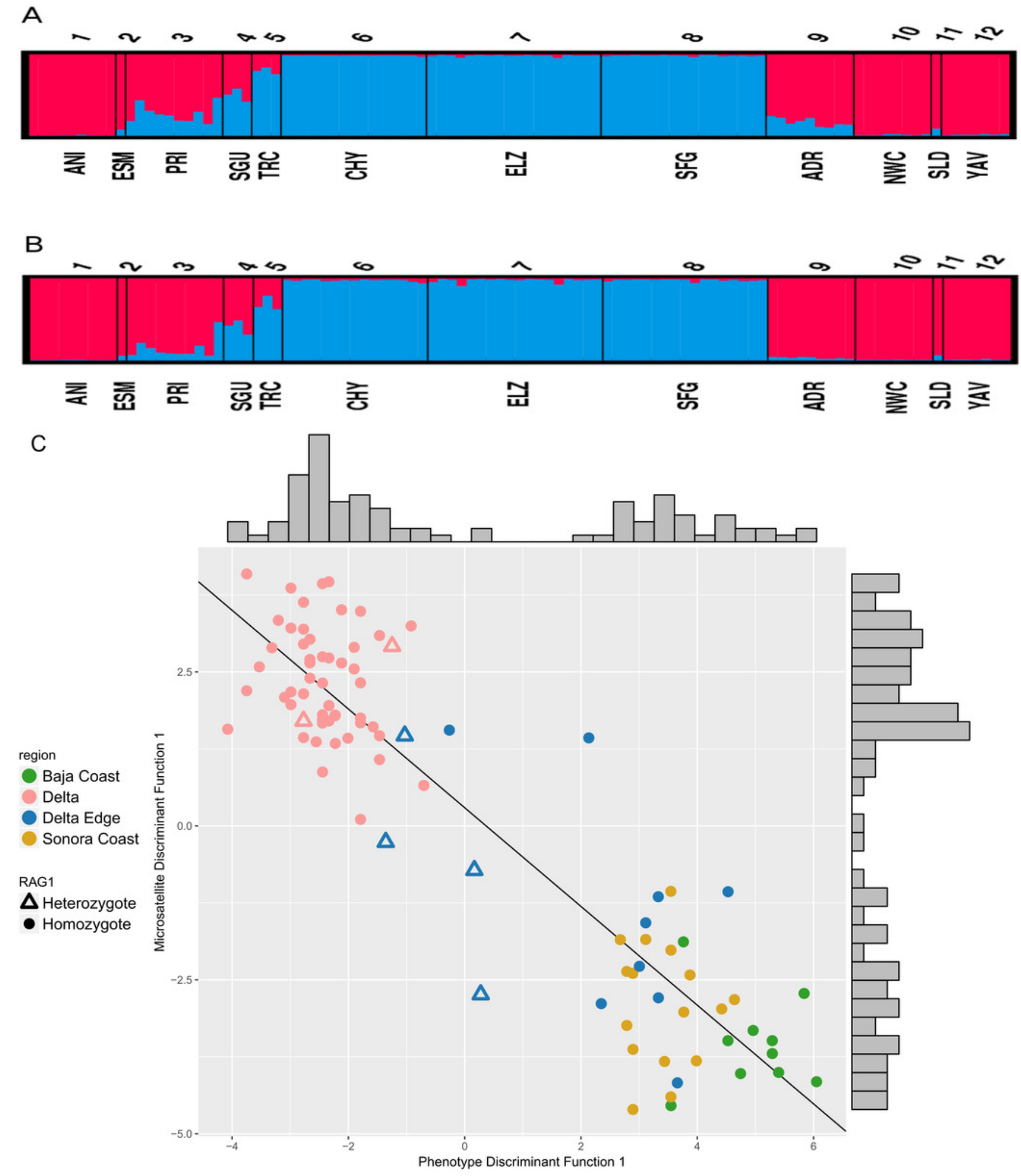


\section{Figure 4}

Cytochrome b haplotype networks

Cyt b median-joining haplotype networks of $C$. hubbsi (A) and C. regis (B). Each circle represents a unique haplotype; size of circles indicates number of specimens with that haplotype. Each tick mark represents a nucleotide difference; black circles represent inferred missing haplotypes. Mismatch distributions for $C$. hubbsi (C) and C. regis (D). Histograms represent the observed pairwise differences; black curves represent the expected pairwise differences under the sudden expansion model. 
A

B

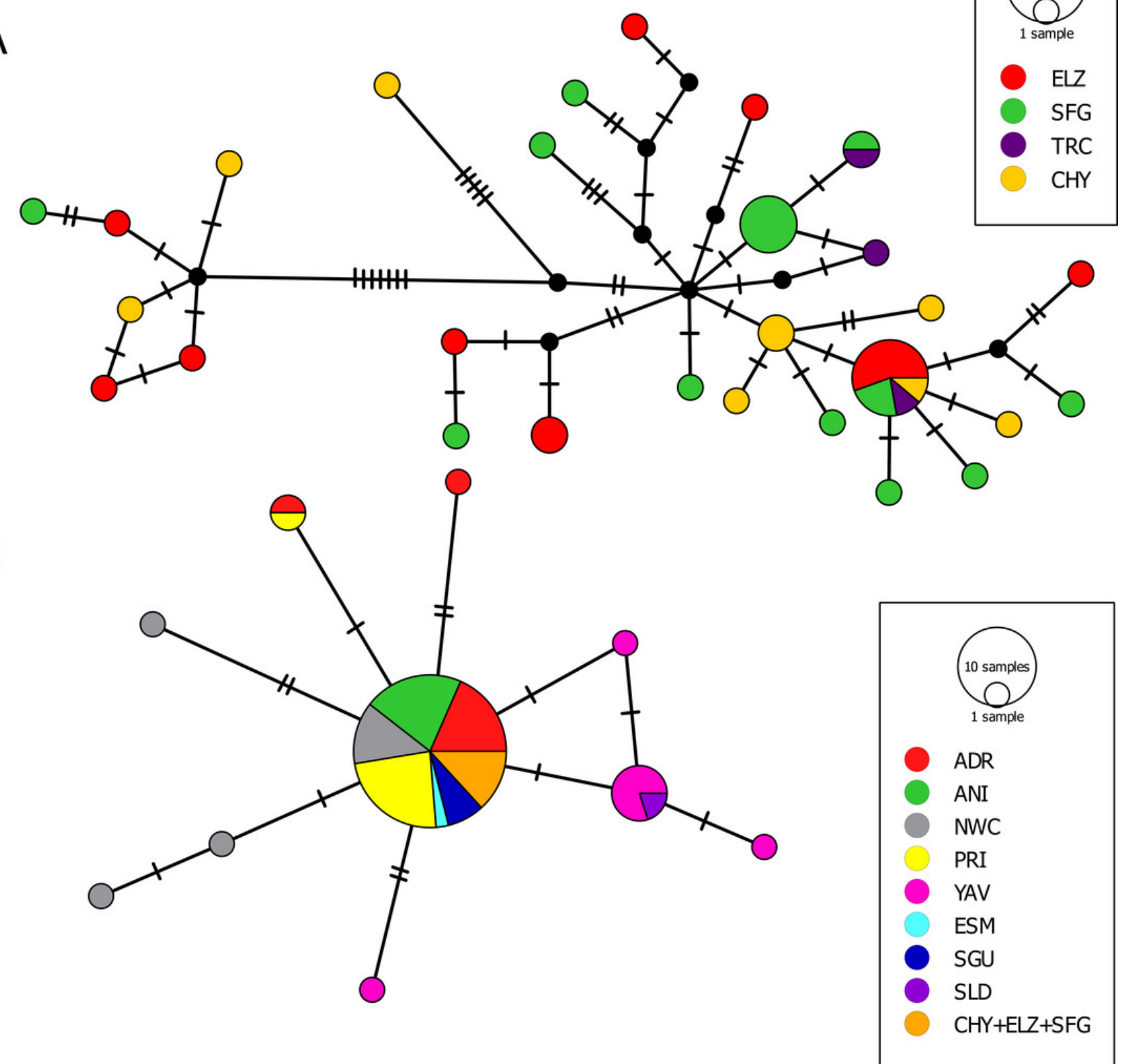

C
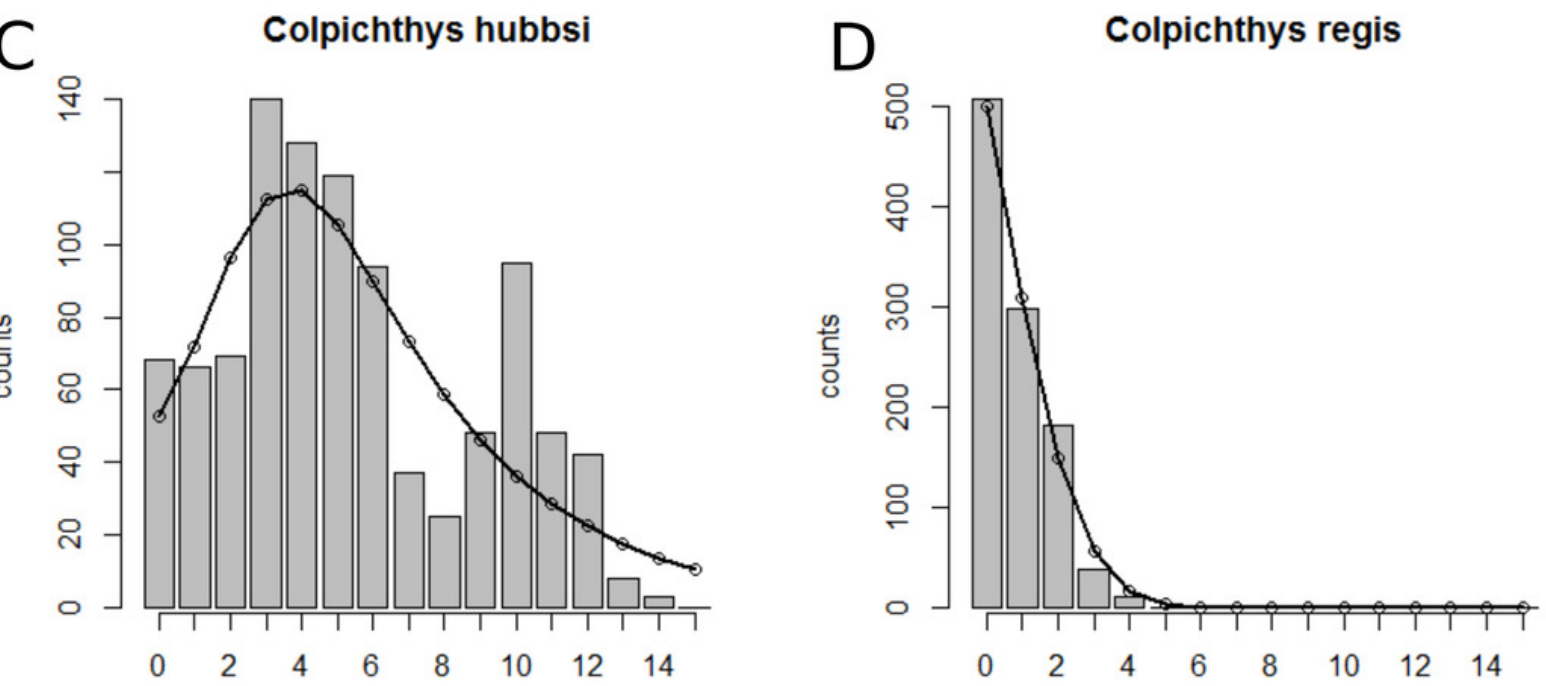


\section{Table $\mathbf{1}$ (on next page)}

Collection localities for the modern specimens.

List of collection localities for the modern specimens. 


\begin{tabular}{|c|c|c|c|c|c|}
\hline$\underline{\text { Locality }}$ & $\underline{\text { Code }}$ & $\underline{\text { Region }}$ & $\underline{\text { Sampling Date }}$ & $\underline{\text { Coordinates }}$ & $\underline{\mathrm{N}=}$ \\
\hline Las Animas & ANI & Baja Coast & 4 May 2007 & $28^{\circ} 47.855 \mathrm{~N}-113^{\circ} 20.894 \mathrm{~W}$ & 9 \\
\hline Estero Santa María & ESM & Baja Coast & 10 Nov 2005 & $30^{\circ} 44.73^{\prime} \mathrm{N}-114^{\circ} 42.01 \mathrm{~W}$ & 1 \\
\hline Estero Primero & PRI & Delta Edge & 22 Sep 2006 & $31^{\circ} 11.903 \mathrm{~N}-114^{\circ} 53.437 \mathrm{~W}$ & 10 \\
\hline Estero Segundo & SGU & Delta Edge & 24 Sep 2006 & $31^{\circ} 15.355 \mathrm{~N}-114^{\circ} 53.011 \mathrm{~W}$ & 3 \\
\hline Estero Tercero & $\mathrm{TRC}$ & Colorado River Delta & 16 Jun 2011 & $31^{\circ} 17.354 \mathrm{~N}-114^{\circ} 54.831 \mathrm{~W}$ & 3 \\
\hline Estero Chayo & $\mathrm{CHY}$ & Colorado River Delta & 3 Dec 2005 & $31^{\circ} 40.119 \mathrm{~N}-114^{\circ} 41.529 \mathrm{~W}$ & 15 \\
\hline "Port Elizabeth" & ELZ & Colorado River Delta & 3 Dec 2005 & $31^{\circ} 49.405 \mathrm{~N}-114^{\circ} 49.566 \mathrm{~W}$ & 18 \\
\hline $\begin{array}{l}\text { "Shrimp Farm” El } \\
\text { Golfo }\end{array}$ & $\begin{array}{l}\mathrm{SFG} / \\
\mathrm{SFGb}\end{array}$ & Colorado River Delta & $\begin{array}{l}2 \text { Dec } 2005 / \\
15 \text { Jun } 2011\end{array}$ & $31^{\circ} 46.480 \mathrm{~N}-114^{\circ} 34.931 \mathrm{~W}$ & $\begin{array}{c}7 \\
12\end{array}$ \\
\hline Bahía Adair & ADR & Sonora Coast & 14 Jun 2011 & $31^{\circ} 32.244 \mathrm{~N}-113^{\circ} 58.910 \mathrm{~W}$ & 9 \\
\hline Northwest of Cholla & NWC & Sonora Coast & 14 Jun 2011 & $31^{\circ} 27.822 \mathrm{~N}-113^{\circ} 37.898 \mathrm{~W}$ & 8 \\
\hline Estero del Soldado & SLD & Sonora Coast & 6 Oct 2006 & $27^{\circ} 57^{\prime} 26^{\prime \prime} \mathrm{N}-110^{\circ} 58^{\prime} 48^{\prime \prime} \mathrm{W}$ & 1 \\
\hline Yavaros & YAV & Sonora Coast & 5 Mar 2006 & $26^{\circ} 40^{\prime} 42^{\prime \prime} \mathrm{N}-109^{\circ} 29^{\prime} 36^{\prime \prime} \mathrm{W}$ & 7 \\
\hline
\end{tabular}




\section{Table 2 (on next page)}

List of museum specimens

List of "historical" specimens from the Natural History Museum of Los Angeles County collection (LACM) and Scripps Institution of Oceanography collection (SIO). 


\begin{tabular}{|c|c|c|c|c|c|c|c|}
\hline$\underline{\text { Collection ID }}$ & $\underline{\text { Collection Date }}$ & $\underline{\text { Locality }}$ & $\begin{array}{l}\text { Locality } \\
\text { Code }\end{array}$ & $\underline{\text { Coordinates }}$ & $\underline{\text { Species }}$ & $\begin{array}{l}\text { Feature } \\
\text { Examined }\end{array}$ & $\underline{N}=$ \\
\hline SIO $81-158$ & 19 Jan 1973 & $\begin{array}{l}\text { East of Isla } \\
\text { Montague }\end{array}$ & EIM & $31^{\circ} 46.0^{\prime} \mathrm{N}-114^{\circ} 42.5^{\prime} \mathrm{W}$ & C. hubbsi & $\begin{array}{l}\text { External } \\
\text { morphology }\end{array}$ & 2 \\
\hline SIO 81-161 & 15 Apr 1973 & $\begin{array}{l}\text { North of Isla } \\
\text { Montague }\end{array}$ & NIM & $31^{\circ} 49.0^{\prime} \mathrm{N}-114^{\circ} 48.5^{\prime} \mathrm{W}$ & C. hubbsi & $\begin{array}{l}\text { External } \\
\text { morphology }\end{array}$ & 1 \\
\hline SIO $81-156$ & 17 Dec 1972 & $\begin{array}{l}\text { West of Isla } \\
\text { Montague }\end{array}$ & WIM & $31^{\circ} 44.0^{\prime} \mathrm{N}-114^{\circ} 48.0^{\prime} \mathrm{W}$ & C. hubbsi & $\begin{array}{l}\text { External } \\
\text { morphology }\end{array}$ & 1 \\
\hline SIO 68-46 & 20 Jan 1968 & $\begin{array}{l}\text { North of San } \\
\text { Felipe }\end{array}$ & SFE & $31^{\circ} 0.0^{\prime} \mathrm{N}-114^{\circ} 52.0^{\prime} \mathrm{W}$ & C. hubbsi* & $\begin{array}{l}\text { External } \\
\text { morphology }\end{array}$ & 16 \\
\hline SIO 60-484 & 5 Dec 1960 & $\begin{array}{l}\text { West from } \\
\text { Empalme }\end{array}$ & EMP & $27^{\circ} 55.0^{\prime} \mathrm{N}-110^{\circ} 55.0^{\prime} \mathrm{W}$ & C. regis & $\begin{array}{l}\text { External } \\
\text { morphology }\end{array}$ & 3 \\
\hline SIO 63-532 & 17 Aug 1963 & Kino Bay & KIN & $28^{\circ} 51.5^{\prime} \mathrm{N}-112^{\circ} 1.5^{\prime} \mathrm{W}$ & C. regis & $\begin{array}{l}\text { External } \\
\text { morphology }\end{array}$ & 1 \\
\hline SIO 63-531 & 17 Aug 1963 & Laguna La Cruz & KNV & $28^{\circ} 48.0^{\prime} \mathrm{N}-111^{\circ} 54.5^{\prime} \mathrm{W}$ & C. regis & $\begin{array}{l}\text { External } \\
\text { morphology }\end{array}$ & 1 \\
\hline LACM 35730 & 23 May 1974 & Guaymas & GYM & $27^{\circ} 55^{\prime} \mathrm{N}-110^{\circ} 57^{\prime} \mathrm{W}$ & C. regis & $\begin{array}{l}\text { Vertebral } \\
\text { morphology }\end{array}$ & 3 \\
\hline
\end{tabular}

* Specimens were classified as C. hubbsi on label, but all except one specimen from this locality display the external morphology of $C$. regis. (For details, see Table S1.) 


\section{Table 3(on next page)}

\section{RAG1 haplotypes}

Variants of RAG 1. $H_{1}, H_{2}, H_{3}$ are common in populations of $C$. hubbsi in the Delta; $R$ is fixed in all populations of $C$. regis. SNPs at positions 717 and 909 (bolded) are species-specific and heterozygotes at these positions are used to identify putative hybrids. 


\begin{tabular}{c|cccc} 
RAG1 Variants & Position 495 & Position 717 & Position 770 & Position 909 \\
\hline$H_{1}$ & $\mathrm{G}$ & $\mathbf{C}$ & $\mathrm{G}$ & $\mathbf{G}$ \\
$H_{2}$ & $\mathrm{G}$ & $\mathbf{C}$ & $\mathrm{T}$ & $\mathbf{G}$ \\
$H_{3}$ & $\mathrm{~A}$ & $\mathbf{C}$ & $\mathrm{T}$ & $\mathbf{G}$ \\
$R$ & $\mathrm{G}$ & $\mathbf{T}$ & $\mathrm{G}$ & $\mathbf{A}$
\end{tabular}


Table 4(on next page)

Distribution of RAG1 heterozygotes

Counts of RAG1 heterozygotes and non-heterozygotes at positions 717 and 909 at each of the Delta and Delta Edge collection sites. 


\begin{tabular}{|c|c|c|c|c|}
\hline & & heterozygotes & non-heterozygotes & het./non-het. ratio \\
\hline \multirow{4}{*}{$\frac{\pi}{0}$} & Port Elizabeth (ELZ) & 0 & 18 & 0 \\
\hline & Shrimp Farm (SFG) & 1 & 15 & 0.067 \\
\hline & Estero Chayo (CHY) & 1 & 12 & 0.083 \\
\hline & Estero Tercero (TRC) & 0 & 3 & 0 \\
\hline \multirow{2}{*}{ 吾 } & Estero Segundo (SGU) & 1 & 2 & 0.500 \\
\hline & Estero Primero (PRI) & 3 & 7 & 0.429 \\
\hline
\end{tabular}

1 


\section{Table 5 (on next page)}

Neutrality tests of Cytochrome b

Neutrality test results. $\mathrm{N}=$ number of samples; $\mathrm{S}=$ number of segregating sites. (Bold: $\mathrm{p}<$ $0.05 ; *: p \leq 0.02 ; * *: p \leq 0.005)$. 
1

Neutrality Tests

\begin{tabular}{cccccccc} 
& $\mathrm{N}$ & $\mathrm{S}$ & $\begin{array}{c}\text { Tajima's } \\
D\end{array}$ & Fu \& Li's $D^{*}$ & Fu \& Li's $F^{*}$ & Fu's Fs & $R_{2}$ \\
\hline C. regis & 47 & 11 & $\mathbf{- 2 . 1 4 1 0 * *}$ & $\mathbf{- 3 . 3 1 1 3 *}$ & $\mathbf{- 3 . 4 5 0 2 * *}$ & $\mathbf{- 7 . 1 7 2 4 *}$ & $\mathbf{0 . 0 5 1 4}$ \\
C. hubbsi & 44 & 40 & $\mathbf{- 1 . 5 6 4 5}$ & $\mathbf{- 2 . 2 3 7 4}$ & $\mathbf{- 2 . 3 7 8 3 *}$ & $\mathbf{- 1 6 . 1 7 8 9 * *}$ & $\mathbf{0 . 0 5 9 6}$ \\
\hline
\end{tabular}

2 


\section{Table 6(on next page)}

Mismatch analysis of Cytochrome b

Mismatch analysis results. SSD = sum of square deviation; $\mathrm{Cl}=$ confidence interval. 
1

\begin{tabular}{ccccrr}
\hline \multicolumn{5}{c}{$\begin{array}{c}\text { Mismatch Analysis } \\
\text { (sudden expansion) }\end{array}$} \\
& SSD & raggedness & $\theta_{0}(99 \% \mathrm{CI})$ & $\theta_{1}(99 \% \mathrm{CI})$ & $\tau(99 \% \mathrm{CI})$ \\
\hline C. regis & 0.0015 & 0.0779 & $0.018(0-0.965)$ & $66842(0-99999)$ & $1.110(0-4.605)$ \\
C. hubbsi & 0.0092 & 0.0158 & $1.332(0-13.558)$ & $17339(6-99999)$ & $5.827(0.105-27.619)$ \\
\hline
\end{tabular}

2 